\title{
En torno a los procesos de la creación artística románica en el medio rural: los tímpanos de Ruiforco y Matueca de Torío (León)
}

\author{
José Alberto MORÁIs MORÁNS \\ Universidad de Extremadura
}

RESUMEN. A través de los tímpanos románicos localizados en Ruiforco y Matueca de Torío (León) se realizan una serie de reflexiones en torno a los procesos de creación escultórica desarrollados por los artífices medievales en el medio rural. El examen detenido de estas piezas aporta datos relevantes sobre la manera de proceder de estos artesanos, las fuentes utilizadas e, incluso, el tipo de relaciones artísticas que se establecían entre los diferentes talleres activos en estas áreas. No en vano, a pesar de los esfuerzos realizados en los últimos años por la historiografía más especializada en torno a esta materia, sigue resultado complicado poder establecer un panorama claro de la manera en que era concebidas las artes plásticas románicas más alejadas de los principales centros de producción artística.

Palabras clave: escultura románica, medio rural, copiar, imitar, iconografía, Agnus Dei, Ruiforco, Matueca, San Isidoro de León, procesos de creación plástica.

ABSTRACT. Through the romanesque tympanum located in Ruiforco and Matueca of Torio (León) we carry out reflections on scuptural creation process which they were carried out by medieval artists in rural circles. A breakdown of these pieces contributes important details about the ways of doing them, their sources and, even, the type of artistic relationship established betwen the different workshops that were runing in these areas. Not for nothing, despite of the efforts realized by the most specialized historiography about this subject during the last years, it's still being complicated to establish a clear view of the way in which romanesque plastic arts away from the were important workplaces were understood.

Key words: Romanesque sculpture, rural circle, coping, imitating, iconography, Agnus Dei, Ruiforco, Matueca, San Isidoro of León, plastic creation process.

A pesar de los esfuerzos realizados en los últimos años por continuar indagando en los procesos de creación artística de las áreas más rurales durante la etapa románica, son muchos los puntos oscuros que aún siguen sin poder esclarecerse. El silencio ofrecido por las fuentes a este respecto nos ha legado una nómina muy reducida de datos absolutos que nos informen sobre la manera de concebir y planificar las obras, los modelos plásticos que tomaron este tipo de artífices secundarios, su procedencia y el papel de los comitentes al respecto.

Las siguientes reflexiones tan siquiera llegan a poner en evidencia tal fenómeno $\mathrm{y}$ apelan a proseguir indagando sobre estos 
temas que tan ricos y sorprendes resultados han ofrecido en las últimas décadas ${ }^{1}$.

A través del análisis de dos tímpanos pertenecientes a las iglesias de los santos Julián y Basilisa de Ruiforco y de San Tirso de Matueca de Torío, ambos en la provincia de León, se deslindan una serie de reflexiones e hipótesis proyectadas a explicar, aunque sea mínimamente, la rica encrucijada de filiaciones, interferencias y diferentes grados de acercamiento a las obras de arte de mayor prestigio y calidad, por parte de los pobres y rústicos escultores de un hóstil medio rural como del que proceden estas dos esculturas que mencionamos (Figs. $1 \mathrm{y}$ 2).

\section{IMITAR LO PRESTIGIOSO. DE LA URBE AL MEDIO RURAL.}

Son pocos los restos materiales de época medieval que han llegado hasta nosotros del desaparecido monasterio leonés dedicado a los santos Julián y Basilisa de Ruiforco. Tan sólo se ha conservado, empotrado en uno de los muros de la iglesia moderna de dicha localidad, un pequeño tímpano románico con la imagen de dos ángeles tenantes elevando la figura del Agnus Dei, representado bajo los convencionalismos del periodo, es decir, con la pata doblada y sosteniendo el lábaro (Fig. 1). El relieve, que posiblemente perteneció a la iglesia del monasterio, representa el ascenso del Cordero inscrito en un clípeo que, a su vez, sirve de enmarque para el desarrollo de esta visión teofánica. Cierran la composición dos elementos vegetales colocados, de manera simétrica, en los extremos

\footnotetext{
${ }^{1}$ Para la elaboración de este trabajo han sido fundamentales las correcciones y consejos sugeridos por la Dra. Concha Cosmen Alonso y Vanessa Jimeno Guerra, a quienes agradezco su ayuda. Igualmente, quiero tener un recuerdo hacia la memoria del Dr. Fernando Galván Freile por la revisión, hace años, de los primeros esbozos de esta aportación que ahora ve la luz.
}

del tímpano ${ }^{2}$. Por su naturaleza, la pieza se ha venido datando en torno a los últimos decenios del siglo XII, aunque si bien el carácter arcaizante que presenta su factura nos podría llevar hasta los primeros años del siglo $\mathrm{XIII}^{3}$.

En todo caso, debemos ser precisos y justificar el uso del adjetivo "arcaizante" que hemos utilizado para referirnos al estilo de su escultura. Así y desde el punto de vista semántico, un elemento o cosa puede considerarse arcaizante cuando imita lo antiguo o emplea de manera reiterada formas anticuadas ${ }^{4}$.

Siguiendo esta idea, el descontextualizado tímpano de Ruiforco de Torío puede ser englobado dentro de una tradición escultórica arcaizante, en la medida en que imita determinadas formas y lenguajes artísticos que, ya por el periodo cronológico en el que fue esculpido, podían ser conside-

\footnotetext{
${ }^{2}$ Sobre la citada obra, véase: M. VALDÉS FERNÁNDEZ, Arquitectura y escultura románicas en León (siglos XI y XII), Astorga, 1985, particularmente, pp. 10-11 y J. M. RODRÍGUEZ MONTAÑÉS, voz «Ruiforco de Torío», Enciclopedia del románico en Castilla y León, León, Aguilar de Campoo, 2002, pp. 203-206.

Una de las primeras alusiones al tímpano en: C. COSMEN ALONSO, E. FERNÁNDEZ GONZÁLEZ Y M. VALDÉS FERNÁNDEZ, «Escultura románica», Historia del Arte en León, León, 1990, en particular, p. 81. Los citados autores se refieren a la pieza en los siguientes términos: "En la misma línea iconográfica, aunque más simplificado y teniendo como motivo central la imagen del Cordero Apocalíptico, se conservan en la provincia de León otras dos piezas de interés. Nos referimos a dos sencillos tímpanos, únicos vestigios, de lo que en tiempos debieron ser otros tantos templos románicos, de Matueca y Ruiforco".

${ }^{3}$ Para M. Rodríguez Montañés la pieza pudo ser labrada en la segunda mitad del siglo XII. Cf.: J. M. RODRÍGUEZ MONTAÑÉS, Ibidem, p. 206.

${ }^{4}$ Voz "arcaico, -ca": Muy antiguo o anticuado. Cf.: Diccionario de la Lengua Española. Vigésima Segunda Edición, Madrid, 2001, en concreto, p. 133. Véase también la voz "arcaísmo": Cualidad de arcaico. Elemento lingüístico cuya forma o significado, o ambos a la vez, resultan anticuados en relación con un momento determinado. Empleo de arcaísmos lingüísticos. Imitación de las cosas de la antigüedad. Cf.: Ibidem, en concreto, p. 133.
} 
radas antiguas o anticuadas. Como intentaremos exponer a lo largo de las siguientes páginas, el escultor que trabajó sobre él, posiblemente realizó una imitación de otra obra de mayor calidad. Ahora bien, debemos preguntarnos cual fue la tradición artística arcaica y en desuso seguida por el maestro local y, más importante, que fue lo que le llevó a continuar participando de dichas soluciones, a pesar de que éstas se encontraban, ya a finales del siglo XII, en plena decadencia.

Imitar es "hacer una cosa a semejanza de otra, tomándola como modelo" ${ }^{5}$, tipo éste último al que el elemento imitador "se parece bastante" ${ }^{\prime \prime}$. En este sentido, el tímpano de Ruiforco es una imitación, bastante aproximada, del modelo al que imita, que en este caso se halla en la Puerta del Cordero de la Real Colegiata de San Isidoro de León (Fig. 3$)^{7}$. Allí, en el acceso meridional al

\footnotetext{
${ }^{5}$ Voz "imitar": Ejecutar algo a ejemplo o semejanza de otra cosa. Dicho de una cosa: Parecerse, asemejarse a otra. Hacer o esforzarse por hacer algo lo mismo que otro o según el estilo de otro. Cf.: Ibidem, p. 848.

${ }^{6}$ Voz "imitación": Acción y efecto de imitar. Objeto que imita o copia a otro, normalmente más valioso: Ibidem, p. 848.

${ }^{7}$ A. VIÑAYO GONZÁLEZ, Real Colegiata de San Isidoro. Historia, Arte y Vida, León, 1998, p. 52; E. FERNÁNDEZ GONZÁLEZ, San Isidoro de León, Madrid, 1992, pp. 24-26; J. W. WILLIAMS, «Generationes Abrahae: iconografía de Reconquista en León», El tímpano románico: imágenes, estructuras y audiencias, Santiago de Compostela, 2003, pp. 155-180, en particular, pp. 173174. Este último experto data la fachada en los años posteriores a la muerte de Alfonso VI (†1109).

Véase también: M. POZA YAGÜE, «Entre la tradición y la reforma. A vueltas de nuevo con las portadas de San Isidoro de León», Anuario del Departamento de Historia y Teoría del Arte, vol. XV, 2003, pp. 9-28, en particular, p. 19; T. MARTIN, «Un nuevo contexto para el tímpano de la Portada del Cordero en San Isidoro de León», El tímpano románico..., pp. 183-205, en concreto, pp. 193-198 y M. A. CASTIÑEIRAS GONZÁLEZ, “La meta del Camino: la catedral de Santiago de Compostela en tiempos de Diego Gelmírez", Los caminos de Santiago. Arte, Historia y Literatura (María del Carmen Lacarra Ducay coord.), Zaragoza, 2005, pp. 213-252, en especial
}

templo legionense, fue esculpido, en torno al año $1100^{8}$, un tímpano en el que aparecían dos ángeles impulsando al Cordero Místico a realizar el movimiento ascensional. Es bien sabida la importancia de esta fachada en cuanto al complejo programa iconográfico que desarrolla ${ }^{9}$, la manifestación plástica del desenvolivimiento de un estilo nuevo que tendría gran repercusión en la escultura románica posterior del ámbito peninsular $\mathrm{y}$, más importante, el papel jugado por esta estructura de acceso al templo románico como un emblema iconográfico visual colocado en una de las partes más visibles de la basílica regia.

La composición formada por dos ángeles y el Agnus Dei elevado a los Cielos de la Puerta del Cordero debió ser entendida, ya por entonces, como una imagen de prestigio. Nos interesa aquí, no el icono/símbolo susceptible de complejas lecturas iconográficas a las que debió ser sometida por parte de los teólogos y los espectadores medieva$\operatorname{les}^{10}$, sino la imagen como un "monumen-

p. 237. El último autor data la fachada en el año 1115.

Finalmente, véanse las aportaciones recientes: F. PRADO-VILAR, «Estilo, genealogía y sacrificio en el arte románico español», Goya, 324, 2008, pp. 173-199; ID., «Lacrimae rerum: San Isidoro y la memoria del padre», Goya, 328, pp. 195-221 y J. A. MORÁIS MORÁN, «La efigie esculpida del Rey David en su contexto iconográfico. Una poética musical para la apotheosis celestial en la portada del Cordero de San Isidoro de León», Imágenes de poder en la Edad Media. Homenaje al Profesor Fernando Galván Freile, León, (en prensa).

${ }^{8}$ Valorar aquí la controversia cronológica relativa a esta portada desviaría nuestro estudio de sus objetivos principales. Aceptamos entonces, la datación tradicional que, desde el punto de vista historiográfico, se ha venido considerando como más acertada.

${ }^{9}$ Últimamente se han planteado o matizado algunos aspectos iconográficos muy concretos de la citada portada. Véase: F. PRADO-VILAR, «Lacrimae rerum...», pp. 195-221.

${ }^{10}$ T. MARTIN, «Un nuevo contexto para el tímpano del Cordero en San Isidoro de León», El Tímpano románico: imágenes, estructuras y audiencias ( $\mathrm{R}$. Sánchez Ameijeiras y J. L. Senra Gabriel y Galán coords.), Santiago de Compostela, 2003, pp. 191-198 e ID., «Decorar, aleccionar, aterrorizar: escultura románica y 
to" de referencia para los escultores coetáneos y los de las generaciones posteriores. Hasta que punto la puerta del Cordero pudo dejar su huella en los maestros contemporáneos, es una cuestión que debemos tener muy en cuenta, sobre todo, a la hora de realizar un primer acercamiento a la escultura de Ruiforco. Su utilización en esta etapa tardorrománica, para enmarcar el acceso a un templo rural, nos habla de la perdurabilidad de aquella como obra prestigiosa, inborrable no sólo en las mentes de aquellos que ideaban los ciclos iconográficos, sino también, en la de los propios artistas, independientemente del rango y destreza que tuviesen. Estas causas, así como el hecho de que nos encontremos ante una visión arquetípica de gran entidad justificaban, plenamente, su colocación en la puerta de la iglesia de San Julián y Santa Basilisa.

No obstante, algunos rasgos separan la representación del Cordero de San Isidoro y la de la iglesia de Ruiforco pero, a pesar de ello, son esas mismas diferencias las que, a nuestro modo de ver, acaban perfilando su carácter imitativo. De esta forma, mientras que en San Isidoro parece claro que el Cordero se eleva al cielo a través de un clípeo perlado ${ }^{11}$, en el caso de la escultura de San Julián y Santa Basilisa, el Agnus Dei es enaltecido, posiblemente, a través de una patena de fines litúrgicos ${ }^{12}$.

gótica», Real Colegiata de San Isidoro: relicario de la monarquía leonesa (C. Robles García y F. Llamazares Rodríguez), León, 2007, pp. 104-143.

${ }^{11}$ Este tipo de decoración debe emparentarse con otra serie de producciones artísticas, vinculadas al arte del metal y la orfebrería. Como veremos, existen paralelos muy cercanos susceptibles de equiparse con esta imagen de San Isidoro. Cf.: J. A. MORÁIS MORÁN, «La efigie esculpida del Rey David...», (en prensa).

${ }^{12}$ Fue el Dr. Manuel Valdés Fernández el primero en exponer esta hipótesis: "En San Isidoro, el Cordero está en el interior de un clipeo perlado, mientras que en Ruiforco (...) está sobre una superficie circular y cóncava que recuerda una patena. Este objeto litúrgico, en su origen correspondía a unas bandejas circulares que tenían como
Teniendo en cuenta lo expuesto y siendo plenamente conscientes de lo hipotético de nuestras afirmaciones, realicemos un ejercicio retrospectivo que nos permita imaginar el proceso de creación de este tímpano.

Como imitador, es posible que el artífice de Ruiforco tuviese un modelo preciso en su mente que, en este caso, parece ser la portada del Cordero de San Isidoro. Sin embargo, deduciblemente, tal referente no debió ser visualizado al natural en el momento de esculpir su obra. Este hecho le lleva a añadir elementos nuevos que se desvinculan ya del modelo primigenio al que imita. Este aspecto es fundamental en el proceso de creación artística durante el periodo románico; un maestro, conocedor de un modelo iconográfico de gran entidad, lo asume, utiliza y modifica en sus creaciones plásticas. En ese proceso el artista aporta, de manera original, diversos aspectos sobresalientes del bagaje que como creador posee. En el caso del tímpano de la iglesia de San Julián el escultor reinterpreta la imagen del tondo isidoriano a través de la creación de una suerte de patena en la que inscribe la figura del Agnus Dei con la $\mathrm{cruz}^{13}$. El enriquecimiento de la imagen se

objeto preparar el pan para la consagración y para su posterior transporte; eran de grandes dimensiones y las sotenian normalmente dos subdiáconos. A fines del siglo XI la misa romana adoptó el pan de ácimo y con ello disminuyó el tamaño de la patena para adaptarse al cáliz, mientras que el pan ya consagrado se colocaba en un copón. Mas tarde en el siglo XII se señaló la patena con una cruz. Si en relación con el tema señalábamos que en las liturgias orientales, una de las partes en las que se fraccionaba el pan, se denominaba Cordero, la lectura queda en parte resuelta". Cf.: M. VALDÉS FERNÁNDEZ, Arquitectura y escultura..., p. 27. Se trata de una patena del tipo crismal que, por su forma cóncava, estaban destinadas a contener el crisma. Cf.: A. GARCÍA FlORES, «La Patena», Maravillas de la España Medieval. Tesoro Sagrado y Monarquía, vol. I, Valladolid, 2001, p. 341.

${ }^{13}$ La relación entre este objeto litúrgico y la cruz está documentada en la Edad Media, por ejemplo, a través de la patena de la abadía benedictina de Santo Domingo de Silos. En ella existe una pequeña cápsula 
produce a través de este proceso de imitación, reflejando el conocimiento de las mismas artes del metal que llevaron a perlar el clípeo de San Isidoro. Así las cosas, no podemos desechar el conocimiento, por parte del artista, de alguna de las numerosas patenas románicas en las que, de manera bien documentada, se grababa la imagen del Cordero potenciando, además, el simbolismo de tal objeto. Sirva a título de ejemplo la célebre patena del abad Pelayo donada a la iglesia berciana de Santiago de Peñalba y ligeramente coetánea al relieve que analizamos ${ }^{14}$ (Fig. 4).

Además de ello, el escultor del tímpano de Ruiforco introdujo otra serie de elementos que, iconográficamente, parecen insinuar un conocimiento más profundo de las fuentes y el simbolismo de la imagen románica que el esperable de un artista secundario. Así por ejemplo, llama la atención que, bajo la estructura circular sobre la que se eleva el Cordero, el artífice haya esculpido una pequeña esfera colocada en el borde inferior sirviendo de base al objeto

o recipiente en cuyo interior se conservaba una cruz patada de oro, a modo de reliquia evocadora del lignum crucis. Cf.: A. GARCÍA FlORES, «117. Patena», Maravillas..., ficha caligráfica $\mathrm{n}^{\mathrm{0}} 117$, p. 342.

${ }^{14}$ Paris. Musée du Louvre. La pieza debió realizarse durante la segunda mitad del siglo XII por encargo del abad Pelayo Fernández, si bien popularmente se atribuye la patena, junto a un caliz, al abad Genadio. Sobre la pieza, y especialmente sobre la inscripción que porta, véase: R. FAVREAU, «Les inscriptions du calice et de la patène de l'abbé Pélage au Louvre», Comptes rendus de l'Académie des Inscriptions et BellesLettres, 1993, pp. 31-48 y V. GARCÍA LOBO y M. E. MARTÍN LÓPEZ, «Errores de rogatario en una inscripción del siglo XII. (A propósito de Les inscriptions du calice et la patène de l'abbé Pélage au Louvre, de Robert Favreau)», Estudios Humanísticos, 17, 1995, pp. 151-161. Debemos aludir también, por presentar características similares, a la patena de la abadía alemana de St. Michael de Siegburg. Sobre la pieza, véase: J. M. PLOTZEK, «Ficha catalográfica D20», Monumenta Annonis. Köln und Siegburg Weltbild und Kunst im hohen Mittelalter, Köln, 1975, p. 179 e I. SIEDE, "Patene von Abt Reginhard", Europas mitte um 1000. Katalog, Stuttgart, 2000, p. 445. litúrgico sobre el que se coloca el Agnus Dei. Pronunciarse sobre su identificación resulta arriesgado, habida cuenta de su omisión dentro del tímpano del Cordero de San Isidoro, su referente original.

A través de la representación del Cordero esculpida sobre un dintel conservado en Museo del Louvre, creemos posible arrojar algo de luz para la identificación de dicho elemento. La pieza francesa muestra un Cordero dentro de un clípeo, nuevamente perlado, sustentando el lábaro. En la parte baja de la composición se esculpió un pequeño círculo similar al leonés y que se ha venido identificando como una materialización del mundo, sobre el cual, el Cordero ejerce su poder ${ }^{15}$. Tal vez el maestro arcaizante de Ruiforco era conocedor de este complejo simbolismo y colocó, no de manera accidental, la imagen del mundus a los pies del Cordero. En todo caso, nuestra teoría no sobrepasa el nivel de la mera conjetura.

Su formación dentro de la más pura tradición simbólica medieval viene avalada, además, por otros elementos. Así, introdujo en cada extremo de la composición dos motivos vegetales que insisten en el carácter simbólico de la imagen y refuerzan, tal y como señala J. M. Rodríguez Montañés, el carácter inmaterial de la visión, sin duda, vinculada a una posible alusión al paraíso ${ }^{16}$.

\footnotetext{
${ }^{15}$ El dintel procede del Languedoc o el Roussillon y se ha datando en torno al año 1100. Cf.: J-R. GABORIT, «Fragment de linteau: inscription et Agneau de Dieu», La France romane au temps des premiers capétiens (9871152), Paris, 2005, ficha catalográfica 65, p. 111.

${ }^{16}$ J. Rodríguez Montañés los describe en los siguientes términos: "Dos representaciones vegetales, un cogollo y una doble hoja nervada de puntas vueltas". Cf.: J. M. RODRÍGUEZ MONTAÑÉS, Op. cit., p. 206 y M. VALDÉS FERNÁNDEZ, Arquitectura y escultura..., p. 27. Este autor identifica dichos elementos como dos flores.

Sobre la importancia y el fuerte simbolismo de lo vegetal dentro de la etapa románica, consúltese: $\mathrm{CH}$. FRUGONI, «Alberi (in Paradiso Voluptatis)», L'Ambiente vegetale nell'alto medioevo, Spoleto, 1990, pp. 727-762.
} 
Quizás nos encontremos ante el recuerdo, materializado mediante un lenguaje escultórico renovado, de la orla vegetal que recorre parte del lado izquierdo del tímpano de la puerta del Cordero en San Isidoro ${ }^{17}$.

En relación con la forma esférica representada bajo la supuesta patena del tímpano de Ruiforco, debemos sugerir una última hipótesis. Para ello recurrimos a las palabras de M. Th. Lyman al explicar la mesa de altar atribuida a Guilduino y realizada para la iglesia de Saint-Sernin de Toulouse. El citado experto interpretaba las doce rosetas esculpidas en los márgenes de la pieza como una alusión simbólica de los doce apóstoles y, mediante ese mismo método, entendía que las doce esferas de los lóbulos que presenta la mesa de altar eran

${ }^{17}$ El motivo vegetal del tímpano del Cordero de San Isidoro puede ser adscrito a los primeros años del siglo XII. Se trata de una cenefa vegetal carnosa, que remarca el sentido teofánico e inmanterial de la visión del Cordero. Además, dicho elemento permite afirmar que, tanto la placa del ángel como la inferior, perteneciente a la escena de Abraham e Isaac; fueron labradas para esa fachada, sin posibilidad de que se trate de fragmentos anteriores recompuestos. Sobre la unicidad y coherencia de todas las piezas, aparentemente removidas, dentro de la fachada del Cordero, cf.: J. A. MORÁIS MORÁN, «La efigie del rey...», (en prensa).

En contraposición, parece claro que las formas utilizadas por el escultor de Ruiforco apuntan a un cambio estético que se deja entrever, tan sólo, en la decoración vegetal. Se trata de los típicos cogollos carnosos habituales dentro de la "estética 1200" y que tanto éxito tendrían, por ejemplo, dentro de la "escuela mateana" que irradió desde la catedral de Santiago de Compostela hacia otros importantes centros, tal y como atestiguan los vegetales del sepulcro de la Magdalena o la Puerta del Obispo de la catedral de Zamora. Cf.: J. D'EMILIO, «Tradición local y aportaciones foráneas en la escultura románica tardía: Compostela, Lugo y Carrión", O Pórtico da Gloria e a Arte do seu Tempo, Santiago de Compostela, 1992, pp. 83-101; J. M. CAAMAÑo MARTínEZ, «Pervivencias y ecos del pórtico de la Gloria en el gótico gallego», O Pórtico..., pp. 439445 y E. FERNÁNDEZ GONZÁLEZ, «Presencia de Oriente y Occidente en la Portada del Obispo de la Catedral de Zamora», Estudios Humanísticos, 1988, León, pp. 225274. una clara referencia simbólica al pan eucarístico $^{18}$.

Por nuestra parte, tan solo proponemos una equiparación formal y simbólica entre este elemento de la mesa de altar y la pequeña esfera de Ruiforco, sin que, por el momento, podamos concretar más su significado.

Como vemos, el escultor rural se nos muestra rico en conocimientos iconográficos y diestro en el campo escultórico; sin embargo, las fórmulas estilísticas a las que recurre tenían por entonces sus horas contadas. La concepción de los ojos almendrados, los cabellos rizosos y, sobre todo, el desarrollo de fuertes mentones y carrillos hichados, colocan a nuestro escultor en una corriente continuista de la tradición más "purista" del románico de las primeras décadas del siglo XII que había llegado a tierras leonesas gracias a los talleres activos en la basílica de San Isidoro ${ }^{19}$. Su estilo de "los carrillos hinchados", tal y como lo definió H. Focillon tuvo, como es bien sabido, su máximo desarrollo dentro de la escultura "hispano-languedociana" ${ }^{20}$. Sin embargo,

${ }^{18}$ M. TH. LYMAN, «La table d'autel de Bernard Gilduin et son ambiance orginelle», Les Cahiers de Saint-Michel de Cuxa, 13, 1982, pp. 53-74, en especial, p. 58. Sobre el contexto escultórico de esta pieza, véase: Q. CAZES Y D. CAZES, Saint-Sernin de Toulouse. De Saturnin au chef-d'oeuvre de l'art roman, Graulhet, 2008.

${ }^{19} \mathrm{~J}$. A. MORAIS MORAN, «Problématique autour du "style des joues bouffies" et de sa diffusion au sein de la sculpture romane hispano-languedocienne», Colloque International et Pluridisciplinaire Effets de style au Moyen Âge, Aix-en-Provence, 2009, (en prensa).

${ }^{20} \mathrm{H}$. FOCILLON, La escultura románica: investigaciones sobre la historia de las formas, Madrid, 1987, pp. 206207. El experto denomina a esta tendencia escultórica de "rostros hinchados", ya que las figuras representadas muestran esta peculiaridad que el autor hace derivar del foco tolosano y que, según él, tendría, a su vez, un origen en las obras ebúrneas tardorromanas. Véase también: S. MORAlejo ÁlvareZ, "Modelo, copia $y$ originalidad en el marco de las relaciones artísticas hispano- francesas (siglos XI- XIII)", Patrimonio artístico de Galicia y otros estudios, 3 vols., Santiago de Compos- 
su manera de hacer agonizaba dentro del cambiante y renovado panorama de la plástica hispana hacia finales del siglo XII. Muestra de este fenómeno es la postura con la que fueron representados los ángeles del tímpano, calificada como una "inverosímil contorsión" ${ }^{\prime 21}$, pero que, según pensamos, no debe explicarse apelando al carácter rural de la obra ni a la poca pericia que el maestro pudiese poseer. Más bien se trataría de un convencionalismo del que gozaron muchas de las representaciones antropomórficas coetáneas. Aludimos en este sentido a una de las obras de patrocinio regio más importantes conservadas en la Cámara Santa de Oviedo: el Arca Santa; obra en absoluto dependiente de una tradición artística rural y en la que, nuevamente, encontramos esta contorsión de los ángeles que elevan a los cielos la mandorla de Cristo $^{22}$.

tela, 2004, vol. II, pp. 75-96. 206

${ }^{21}$ J. M. RODRÍGUEZ MONTAÑÉS, «Ruiforco...», p.

22 E. FERNÁNDEZ GONZÁLEZ, "El Arca Santa de Oviedo y sus precedentes. De Alfonso II a Alfonso VI" (en prensa). Agradezco a la autora su amabilidad al permitirme consultar el trabajo, antes de su publicación.

Véase también: R. AlONSO ÁlVAREZ, «Arca Santa o Arca de las Reliquias», Maravillas de la España Medieval. Tesoro sagrado y Monarquía, León, 2001, vol. I, ficha catalográfica 160, pp. 398-400; ID., «Patria uallata asperitate moncium: Pelayo de Oviedo, el "archa" de las reliquias y la creación de una topografía regia», Locus Amoenus, 9, 2007-2008, pp. 17-29 y J. A. HARRIS, «Redating the Arca Santa of Oviedo», The Art Bulletin, 77, 1995, pp. 82-93, particularmente, p. 83 y p. 90.

Desde otro orden de cosas, encontramos estas posturas en ángeles tenantes esculpidos en centros de primer orden. Recuérdese el caso del gran tímpano de la iglesia de Saint-Lazare de Autun o los más tempranos de Saint-André-de-Sourede o Saint-Genis-lesFonts. En el caso hispano, nuevamente se repite esta problemática a la hora de representar las figuras angélicas elevando el clípeo en la iglesia gallega de Santa María de Cambre. Cf.: M. CHAMOSO LAMAS, V. GONZÁLEZ y B. RegAL, Galice Romane, Yonne, 1973, en particular, pp. 384-385.

Sin duda, se trata de un rasgo común derivado de la complejidad de captar el impulso del cuerpo que
Además, y esta puede ser la justificación más factible para explicar la postura de los ángeles del tímpano de Ruiforco, asistimos, en los últimos años del siglo XII, a la disolución de la corriente escultórica nacida en el seno de los talleres escultóricos de San Isidoro de León, menos activos desde la consagración final del edificio en el año $1147^{23}$. Con la desmembración de los talleres de escultura que hasta el momento habían trabajado en el edificio, podemos suponer un declive de las formas irradiadas desde allí, así como una reiterativa emulación inercial de las mismas que, como en toda imitación, acabarían por resultar arcaizantes. El relieve de Ruiforco ejemplifica perfectamente este fenómeno.

\section{LA DIFUSIÓN DE LO IMITADO: LA COPIA.}

Según indicó hace tiempo el profesor Serafín Moralejo, copia "en su rigurosa acepción técnica, no contempla sólo o tanto el grado de adhesión de una obra a un modelo como su voluntad global de evocarlo o de representarlohacerlo de nuevo presente- en su ausencia. Entendida la obra de arte como signo, copia es aquella obra que se agota en la pura referencia a su modelo; no basta con que lo imite; tiene que además significarlo. La copia es un signo de otro

empuja un peso hacia arriba con intención de elevarlo.

${ }^{23}$ La inscripción del 6 de marzo del año 1147, una consecratio ubicada en el brazo sur del crucero, señala este año como fecha indiscutible para la consagración del templo; hecho que no indica que las obras estuviesen totalmente finalizadas pues, en fechas posteriores, se han documentado en la basílica otros trabajos de menor envergadura. Cf.: V. GARCÍA LOBO, «Las inscripciones medievales de San Isidoro de León. Un ensayo de Paleografía epigráfica medieval», Santo Martino de León. Ponencias del I Congreso Internacional sobre Santo Martino en el VIII centenario de su obra literaria (1185-1985), León, pp. 373-397, en especial, p. 386 y S. DOMÍNGUEZ SÁNCHEZ, «Las fórmulas diplomáticas latinas en epigrafía», Documenta E Instrumenta, 6, 2008, pp. 179-200. 
signo" $^{24}$. Es decir, entendemos que copia significa, textualmente, "obra de arte que reproduce fielmente un original" $\mathrm{o}$, de otra manera, "imitación servil" de un modelo preexistente ${ }^{25}$.

Como es sabido, la copia se nos presentó, durante los siglos del románico, como uno de los mecanismos nucleares en cuanto a la creación y génesis de modelos y formas. En una sociedad donde la imagen se transmite de unas generaciones a otras a través de la imitación pero, sobre todo, mediante la copia, la reproducción exacta de un modelo anterior ya existente, debe ser diferenciada, nítidamente, de la imitación ${ }^{26}$.

Ambos conceptos, ocasionalmente, se han venido utilizando indistintamente por parte de los historiadores del arte. A veces usados como sinónimos, la imitación y la copia corresponden a dos niveles muy diferentes de aproximación a la obra artística por parte de los escultores románicos. La copia, a diferencia de la imitación, pretende alcanzar mayores grados de similitud con respecto al modelo inspirador $\mathrm{y}$, mientras que a través de la imitación el artista no puede dejar de imponer determinados rasgos propios de su criterio, fruto de su independencia intelectual; mediante la copia, el

${ }^{24}$ S. MORAlejo ÁlvareZ, «Modelo, copia y originalidad, en el marco de las relaciones artísticas hispano-francesas (siglos XI-XIII)", V Congreso Español de Historia del Arte, Barcelona, 1984, pp. 89-106, en particular, p. 89.

${ }^{25}$ Voz "copia": "Acción de copiar (...) Reproducción exacta de un objeto por medios mecánicos. Imitación de una obra ajena, con la pretensión de que parezca original. Pintura o efigie que representa a alguien". Cf.: Diccionario..., en particular, p. 440

${ }^{26}$ Sirva de ejemplo el conocido sistema de copia de libros, textos e imágenes desarrollado por los scriptoria medievales. Cf.: G. LIPPOLD, voz «Copie e copista», Enciclopedia dell'arte antica classica e orientale, vol. II, Roma, 1959, pp. 804-810 y J. WIRTH, «Copie en miroir: copie au miroir?», Materiam Superabat Opus. Hommage à Alain Erlande-Brandenburg, Paris, 2006, pp. 265-277. artífice reinterpreta el modelo, pero lo hace mecánicamente buscando la exactitud y similitud con respecto al original. En la copia, poco o casi nada se deja a la improvisación, frente a la ineludible imposición del sello personal que conlleva toda imitación. La imitación "se parece bastante" 27 . La copia es una "reproducción con visos de exactitud" 28 .

Regresemos al tímpano de Ruiforco. Tal y como anunciamos se trata de una evocación, bastante aproximada, del tímpano de la portada del Cordero de San Isidoro de León y al que muy posiblemente imita.

En relación con ambas obras fue esculpido, en una cronología incierta, un tercer tímpano, que hoy se conserva en la iglesia de San Tirso de Matueca de Torío, en León (Fig. 2) ${ }^{29}$. La pieza, desde el punto de vista compositivo, presenta total similitud con respecto al relieve de Ruiforco. Nuevamente aparecen dos ángeles tenantes que, con su impulso, elevan al Agnus Dei. Se repiten idéticas posturas e iconografía e incluso reaparecen en los extremos los elementos vegetales anteriormente mencionados.

${ }^{27}$ Véase la nota 7 de este estudio.

${ }^{28}$ Véase la nota 25 .

${ }^{29}$ Esta localidad leonesa se halla a escasos cinco kilómetros de Ruiforco, mientras que son apenas diecinueve los que la separan de la ciudad de León. El templo actual fue construido en el siglo XVIII, sin embargo, parece que los restos románicos que hoy se observan en diferentes partes del pueblo de Matueca fueron trasladados desde la cercana población de Otero. En este sentido, frente al silencio documental durante la Edad Media sobre este lugar, Otero sí aparece citado ya en un documento de confirmación de propiedades de Fernando II a la Orden de Santiago, en el año 1181, lo que ha hecho pensar que este tímpano de Matueca perteneciese, en origen, a Otero. A partir de este momento, las alusiones al tímpano se realizarán mediante el topónimo del lugar donde hoy se conserva, independientemente del sitio del que provenga. Sobre la pieza, véase: N. BAYÓN RODRÍGUEZ, «Matueca de Torío», Enciclopedia del Románico..., pp. 177-178. 
Según se ha expuesto, podemos hablar de "una clara imitación" del tímpano de Matueca con respecto al de Ruiforco ${ }^{30}$ pero, tal y como podemos deducir a tenor de lo expuesto anteriormente, en nuestra opinión se trataría, más exactamente, de una copia. El escultor ha tomado como modelo directo el tímpano de Ruiforco, asumiendo hasta los más pequeños detalles. El espacio para la improvisación y la introducción de nuevos elementos no existe. A diferencia de la imitación realizada por el escultor de Ruiforco, quién sometía a reinterpretación libre algunos de los elementos presentes en el modelo al que imitaba, es decir, la escultura de la Puerta del Cordero de San Isidoro, el autor del tímpano de Matueca no aporta nada nuevo a la obra; reproduciendo exactamente el modelo original, mediante una técnica y destrezas ciertamente inferiores.

Para intentar clarificar nuevamente el proceso seguido por los escultores para generar esta copia, irremediablemente nos vemos empujados, otra vez, a adentrarnos en el campo de las hipótesis. $\mathrm{Al}$ reconstruir tal proceso, primeramente, debemos preguntarnos por las razones que llevaron a un escultor rural como el que elaboró la escultura de Matueca de Torío a intentar copiar la imagen de Ruiforco. La misma cuestión surge al indagar en las causas por las cuales se conformó simplemente en copiar una obra que, a su vez, imitaba otro modelo de mejor calidad y prestigio sin intentar ofrecer su propia revisión del tímpano de San Isidoro.

En todo caso, durante la elaboración de esta escultura, resulta especialmente interesante el momento en el que fue materializada. Las fuertes deudas del tímpano de Matueca con respecto al de Ruiforco podrían insinuar, en un primer acercamiento, que la copia debió realizarse delante del

\footnotetext{
${ }^{30}$ N. BAYÓN RODRÍGUEZ, Op. cit., p. 178.
}

modelo original antes de que este fuese colocado en su lugar correspondiente dentro del acceso al templo o una vez que este se encontraba ya en la parte alta de la iglesia de San Julián.

Sin embargo, apelando a la coherencia más realista, resulta poco probable que un escultor hubiera desplegado sus instrumentos de trabajo y el gran bloque pétreo en el que realizaría el relieve de Matueca delante mismo de la portada de Ruiforco.

Lo que a continuación intentaremos justificar es la utilización, por parte del artífice, de un dibujo previo a la intervención sobre la piedra; un diseño orientativo que -a juzgar por las semejanzas entre ambos tímpanos- debió ser un calco absolutamente fiel del tímpano de Ruiforco.

Todas estas cuestiones que pudieran parecer en un primer momento insignificantes son, a posteriori, muy interesantes para poder clarificar, aunque sea superficialmente, determinados aspectos relativos al sistema de trabajo de los escultores románicos y, más concretamente, aquellos que realizaron sus producciones artísticas en un medio rural.

Se trata de un tema muy estudiado pero minimizado ante el escaso número de datos que nos han privado obtener las ricas conclusiones que el tema ofrecería. Nuestro desconocimiento sobre el método de trabajo de estos artífices activos en el medio rural, viene avalado, además, por la falta de fuentes y de documentos que lo aclaren. Pocos o casi ninguno de estos diseños o bocetos preparatorios han llegado hasta nosotros desde las manos de los artistas más rústi$\cos ^{31}$. Según pensamos, aunque sea de ma-

\footnotetext{
${ }^{31}$ Sobre el proceso de creación artística a través del conocido sistema de los "libros de modelos", véase: M. BARASCH, Teorías del Arte. De Platón a Winckelmann, Madrid, 1999, pp. 77-82; A. NESSELRATH, «I libri di disegni di antichità. Tentativo di una
} 
nera indirecta, el caso del tímpano de Matueca nos sugiere su posible existencia.

A juzgar por su filiación estilística y formal, este relieve se debió realizar en una fecha ligeramente posterior a la del de Ruiforco, muy posiblemente, en los inicios del siglo XIII. Esta cronología imposibilita que ambas obras fuesen esculpidas al mismo tiempo y, desde el punto de vista formal, también resulta improbable que en ambos relieves interviniese un mismo escultor o idéntica mano ${ }^{32}$.

Frente a la poca probable ejecución de un tímpano en piedra delante de la portada de otro templo, creemos que el torpe escultor del tímpano de Matueca realizó, al natural, un diseño preparatorio de lo que después trasladaría a la piedra. Estamos afirmando con ello la posibilidad de que, aún a pesar de hallarnos en un medio rural, el maestro que copió toda la composición y los detalles más pequeños del tímpano modelo, previamente, trasladó aquella obra que tenía ante los ojos a una materia flexible.

La problemática a la hora de poder afirmar con seguridad si los artistas rurales utilizaron la práctica del dibujo y el uso de diseños preparatorios viene incrementada por su total desaparición; fenómeno relacionado con la naturaleza deleble en los que, deductiblemente, fueron realizados estos ensayos iniciales. Sin embargo, a lo largo de la Edad Media y en el caso hispano

tipologia», Memoria dell'antico nell'arte italiana. Dalla tradizione all'archeologia (A cura de S. Settis), vol. III, Torino, 1986, pp. 7-85 y R. BECHMANN, Villard de Honnecourt. Le pensée technique au XIIIe siècle et sa communication, Paris, 1993, especialmente, pp. 122-130.

${ }^{32}$ Todos los autores coinciden en señalar que ambos tímpanos pertenecen a manos diferentes. Cf.: M. VALDÉS FERNÁNDEZ, Arquitectura y escultura..., p. 27; J. M. RODRÍGUEZ MONTAÑÉS, Op. cit., p. 206 y N. BAYÓN RODRÍGUEZ, Op. cit., p. 178. Si bien los citados expertos señalan su pertenencia a la segunda mitad del siglo XII. en particular, han perdurado otros dibujos incisos sobre materias duras que nos revelan el complejo proceso de planificación de una obra. Nos referimos, por ejemplo, a las denominadas monteas pétreas reempleadas como sillares de muro en muchas construcciones románicas y góticas ${ }^{33}$. Así deben recordarse, por su expresividad, el diseño inciso en el cimacio pétreo de la catedral románica de Pamplona, donde fueron grabados dos pisos de arquerías, quizás relacionadas con la planificación de una obra arquitectónica monumental ${ }^{34}$. A este resto pétreo debemos sumar, además, otros dibujos, como el del arco polilobulado grabado sobre madera y relacionado con la Cámara Santa de Oviedo ${ }^{35}$. Un vestigio excepcional que confirma el uso de dibujos preparatorios o ensayos anticipatorios por parte de los artistas durante la Plena Edad Media ${ }^{36}$.

-

33 J. A. RuIz DE LA RosA, Trazas y Simetría de la Arquitectura en la Antigüedad y Medievo, Sevilla, 1987, en particular, pp. 280-290.

${ }^{34}$ M. MELERO MONEO, «Cimacio con arquerías», Sancho el Mayor y sus herederos. El linaje que europeizó los reinos hispanos, Pamplona, 2006, vol. II, ficha catalográfica 280 , pp. 944-945. La autora no pone en duda que se trate de un diseño preparatorio de una obra monumental, sino que considera insuficiente este testimonio como para poder afirmar, a partir de él, que el claustro de la desaparecida catedral románica de Pamplona y del que tan sólo restan varios capiteles, tuviese dos galerías superpuestas.

35 E. FERnÁNDEZ GONZÁLEZ, «El Arca Santa de Oviedo...», (en prensa).

${ }^{36}$ J. A. RUIZ DE LA ROSA, Op. cit., en concreto, p. 224. La importancia del dibujo en la Edad Media queda atestiguada por estos diseños, a veces entendidos como una simple práctica lúdica. Recuérdense los inexpertos grafitos, datados en el siglo $\mathrm{X}$, de la iglesia berciana de Santiago de Peñalba. Estos dibujos, lejos de poder tener un fin artístico, evidencian al menos el interés -nunca perdido- por el diseño y el dibujo durante los siglos medievales. Cf.: B. MARTínEZ FUERTES, Montes y Peñalba: Ensayo Histórico-Artístico, Santiago de Peñalba, 2004, especialmente, pp. 108-119; A. M. MARTÍNEZ TEJERA, «Peñalba de Santiago», Enciclopedia del románico..., pp. 359-370 y M. GUARDIA PONS, «De Peñalba de Santiago a San Baudelio de Berlanga. La pintura mural de los siglos X y XI en el Reino de León y Castilla. ¿Un espejo de Al-Andalus?», El legado de Al- 
Otro caso menos dudoso lo ofrece la montea conservada en el Museo Diocesano de la catedral de León. En este bloque de piedra fue inciso un dibujo preparatorio para uno de los rosetones que, más tarde, se construirían a escala monumental en el hastial norte de esta catedral gótica ${ }^{37}$.

Las similitudes formales entre los dos tímpanos románicos, imposibles de explicar argumentando la pericia mnemotécnica del escultor, permiten afirmar que también en este caso existió un diseño preparatorio, necesario para realizar una copia tan fidedigna de la obra. La materia blanda en la que, posiblemente, se realizó, acabó por perderse y con ella la posibilidad de explicar una de las partes más importantes en la secuencia productiva de este escultor $^{38}$.

Concluyendo, podemos afirmar que la copia de Matueca se nos presenta como una interpretación, pretendidamente original, de su modelo inspirardor ${ }^{39}$ : el tímpano

Andalus. El arte andalusí en los reinos de León y Castilla durante la Edad Media, Valladolid, 2007, pp. 117-155, concretamente, p. 119, nota 8 e ID., «Los grafitos de la iglesia de Santiago de Peñalba. Scariphare et pingere en la Edad Media», Patrimonio, 33, 2008, pp. 51-58.

${ }^{37}$ La montea apareció hace algunos años cuando se llevaron a cabo varios desmontes en el brazo sur del transepto de la catedral. Según parece, diseños similares a este se encontraban en otras piezas procedentes del mismo lugar. Cf.: M. V. HerRÁEz OrTeGA, «La construcción del templo gótico», La catedral de León en la Edad Media, León, 2004, pp. 145-176, en particular, pp. 173-174 y M. VALDÉS FERNÁNDEZ, C. COSMEN Alonso y M. V. HerRáez ORTEGA, «La Edad Media. Del origen a la consolidación del templo gótico», Una historia arquitectónica de la catedral de León (M. Valdés coord.), León, 1994, en particular, pp. 105-106.

En el ámbito europeo destacan las monteas de la catedral de Auxerre, las de la nave y claustro de Noirlac, el fuste de la abadía de Byland o la montea de rosetón de la catedral de Soissons. Cf.: J. A. RUIZ DE LA ROSA, Op. cit., pp. 280-290.

${ }^{38}$ No creemos necesario insistir entre las similitudes formales existentes entre ambos tímpanos.

${ }^{39}$ Usamos la definición dada por el Diccionario de la Real Academia para referirse a la copia. de Ruiforco. Su esencia de copia transforma de manera evidente la imagen primigenia que da origen al modelo -la Puerta del Cordero de San Isidoro- y suma a su interpretación, además, la degradación implícita que toda copia rural de una obra de mayor calidad siempre lleva consigo. A pesar de ello, el artista debió practicar un sistema de ejecución artística muy difundido durante el inicio de este siglo XIII: los libros de modelos y diseños, fuente inagotable para la realización de copias durante toda la Plena y Baja Edad Media, incluso en las fábricas y artífices más modestos.

\section{CUANDO SE SUPERAN LOS NIVE- LES DE IMITACIÓN Y COPIA. EL NACIMIENTO DE LOS ARQUETI- POS ICONOGRÁFICOS.}

Según el Diccionario de la Real Academia de la Lengua Española, el término arquetipo deriva directamente del griego archo, es decir, literalmente -ser el primero-, y del sufijo typos, modelo ${ }^{40}$. El vocablo, entendido desde el punto de vista de las artes figurativas, alude al modelo original y primario que genera un tipo supremo o prototipo ideal que, con el tiempo, acabará convirtiéndose en un modelo a seguir. Es decir, al hablar de arquetipos desde la perspectiva de la historia del arte, debemos pensar en una determinada imagen o forma que, tras ser imitada y copiada a lo largo de los siglos, llega a adquirir valores que le son extrínsecos y que aportan a dicho elemento un nuevo carácter del que antes carecía: el valor y entidad como imagen ${ }^{41}$.

40 voz "Arquetipo", Diccionario..., p. 141.

${ }^{41}$ El proceso es similar al defendido por Alö̈s Riegl para justificar, mediante el concepto "valor de antigüedad", la categoría de "obras de arte" que han recibido determinado tipo de producciones artísticas simplemente por gozar del valor otorgado por el paso del tiempo y que cargan dichas producciones de una importancia netamente histórica, que no artística. En este sentido, una imagen adquiere la categoría de 
Tal potestad como icono viene avalada por su éxito dentro de las artes de periodos pasados que le han llevado a ser imitada y copiada de manera reiterativa, hasta el punto de ser imposible vislumbrar su origen y lugar de génesis y que hace también improbable intuir su desaparición dentro de la historia de las formas y las imágenes ${ }^{42}$.

Regresemos nuevamente a la imagen del Cordero inscrito en un tondo, independendientemente de que éste sea elevado por ángeles tenantes. No es necesario incidir en su importancia desde los primeros siglos del arte cristiano primitivo como encarnación de la víctima propiciatoria del sacrificio en el holocausto. Su reiteración dentro de los programas icónicos de las obras patrocinadas por los primeros cristianos explica su importancia dentro de las artes posteriores ${ }^{43}$.

En el caso hispano, que es el que nos ocupa, la imagen gozó de gran éxito, mostrando un dilatado recorrido a lo largo de la

arquetipo una vez que ésta ha conseguido, mediante su reiteración en el medio artístico, una entidad como imagen prototipo que le sirve para ser reutilizada sin solución de continuidad. Si una producción del siglo $X$ adquiere, mediante el "valor de antigüedad", la condición de "monumento artístico", una imagen del siglo $\mathrm{X}$, simplemente por su categoría como imagen ancestral de gran tradición, también goza de este valor por el mismo mecanismo de tal categoría, convirtiéndose en un arquetipo o modelo a seguir. Cf.: A. RÏEGL, $E l$ culto moderno a los monumentos, Madrid, 1999, pp. 4956, especialmente, p. 50. Véase también: J. GARCíA NISTAL, «La memoria de la Antigüedad en las armaduras de cubierta y sus diferentes vías de difusión. Reflexiones sobre la historia de los ornamentos», Art $i$ Memoria, Barcelona, 2008, (en prensa). Agradezco al autor la posiblidad ofrecida para consultar el manuscrito original de su estudio.

${ }^{42}$ F. SAXL, «Continuidad y variación en el significado de las imágenes», La vida de las imágenes, Madrid, 1989, pp. 11-20.

${ }^{43}$ J. A. MARTignY, voz "Agnus Dei", Diccionario de Antigüedades Cristianas, Madrid, 1894, pp. 30-32 y F. TRISTAN, Les premières images chrétiennes. Du symbole à l'icône: II-VIe siècle, Poitiers, 1996, pp. 123-141. misma historia de las imágenes que acabará por convertirla en una imagen arquetipo ${ }^{44}$. La importancia que la figura del Cordero había tenido en el Antiguo Testamento (Génesis 22, 7-8 y Éxodo 12, 3-21), entendido como símbolo del sacrificio en la fiesta de la Pascua del Señor, se repite en los textos neotestamentarios con las alusiones directas al Cordero como prefiguración de Cristo: "Porque Cristo, que es el Cordero de nuestra Pascua, fue muerto en sacrificio por nosotros" (1 Corintos 5, 7).

Por su parte, San Juan dejó constancia del texto más difundido en relación con el tema que nos ocupa: "He aquí el Cordero de Dios, ved aquí el que quita los pecados del mundo" (Juan 1, 29). Sin embargo, en el occidente cristiano y, de igual manera, en los reinos hispanos, la imagen del Cordero no dejó de utilizarse nunca, reafirmando su carácter arquetípico dentro de los programas artísticos medievales.

A tenor de lo expuesto, podemos concluir que la imagen del Cordero de la puerta de la Real Colegiata de San Isidoro de León pudo ser imitada por el escultor del tímpano de Ruiforco y, posteriormente, otro artista de Matueca acabaría por realizar, a su vez, una copia directa de este modelo.

\footnotetext{
${ }^{44}$ Sin ánimo de ser exhaustivo, debemos destacar varios ejemplos dentro del arte generado entre los siglos IV-X en la Península Ibérica. Recordemos así la célebre imagen de la llamada lauda sepulcral de Ampelius hallada en la necrópolis paleocristiana de Tarragona. La imagen del Cordero fue colocada, entre otros símbolos, con el crismón y la crátera de la vida. Además, la figura se recorta sobre un rico fondo vegetal, alusivo a la visión etérea e inmaterial en la que se inscribe la composición. No debemos olvidar que también los tímpanos de San Isidoro de León, Ruiforco y Matueca, acompañaban la representación del Cordero con sendos elementos vegetales. Cf.: P. PALOL, Arte paleocristiano en España, Barcelona, 1960, en especial, p. 284 y P. BAtlle Huguet, «Arte Paleocristiano», Ars Hispaniae, Barcelona, 1947, pp. 183-223, particularmente, p. 221. Se ha datado el mosaico en el siglo IV.
} 
Con todo, tanto la imagen de San Isidoro, como las derivadas de ella, forman parte de un mismo fenómeno. Con su simple presencia, tales iconos contribuyeron a la gestación de una imagen arquetípica copiada e imitada a través de los siglos. Ello hace posible afirmar que, por ejemplo, la imagen pintada sobre el acceso a la basílica isidoriana desde el Panteón Real y en la que se representaron dos ángeles tenantes elevando un tondo en el que aparece inscrita, nuevamente, la imagen del Cordero; deba ser entendida no como el modelo de inspiración para la escultura de la portada de la iglesia, sino como un estadio más en el desarrollo de tal arquetipo. Las semejanzas entre estos ejemplos citados se deben a su mismo origen y a su participación en una serie iconográfica que acabaría por contribuir a la creación del comentado arquetipo que venimos analizando ${ }^{45}$.

Comparar la composición de los tímpanos de Ruiforco o Matueca, con otros de similar organización, como los gallegos de Santa María de Cambre ${ }^{46}$, San Juan de Mo-

\section{-}

${ }^{45}$ Las pinturas del Panteón Real de San Isidoro de León han recibido diferentes dataciones. Desde la postura tradicionalista que las clasificaba en un avanzado siglo XII, a la tendencia más actual que las engloba dentro de los primeros años de ese mismo siglo. La imagen del Cordero ha sido relacionada con las pinturas de la iglesia francesa de Saint-Savin-sur-Gartempe. Sin embargo, creemos que sus coincidencias formales se deben más a la participación de ambas imágenes de un mismo origen arquetípico que a la dependencia de León con respecto a las galas. Cf.: J. MAYER, «La peinture murale romane», La France romane..., pp. 31-33; A. VIÑAyO GonZÁleZ, Pintura románica: Panteón Real de San Isidoro, León, 1979 y M. A. CASTIÑEIRAS GONZÁLEZ, «El Programa Enciclopédico de la Puerta del Cielo en San Isidoro», Compostellanum, vol. XLV, no 3 y 4, 2002, pp. 657-694.

${ }^{46}$ Se suele considerar el tímpano de esta iglesia benedictina de A Coruña como uno de los primeros ejemplos de la citada iconografía en suelo gallego. Cf.: R. SÁNCHEZ AMEIJEIRAS, «Algunos aspectos de la cultura visual en la Galicia de Fernando II y Alfonso IX», El arte románico en Galicia y Portugal, La Coruña, 2001, pp. 157-175, en particular, p. 158. raime ${ }^{47} \mathrm{o}$ los pertenecientes a ámbitos más alejados, como el de la iglesia de San Andrés de Armentia ${ }^{48}$; por una parte, reafirma la participación de tales ejemplos en la gestación de una imagen arquetípica $y$, por otra, revela la inestabilidad y el carácter hipotético de las supuestas filiaciones que, en ocasiones, establecemos los estudiosos del arte medieval. Este tipo de concomitancias corresponden más a criterios de simple semejanza formal, característica básica del arquetipo, que a una dependencia real y veraz de un modelo con respecto a otro.

Siguiendo esta misma línea, podemos afirmar que, igualmente arquetípica, resulta la ubicación de la imagen del Agnus Dei en los accesos a los templos. Desde la portada de la iglesia de Santa María Magdalena de Vézelay (ca. 1135-1140) ${ }^{49}$, en la que nos recibe la monumental imagen de San Juan Bautista que sujeta la patena en la que se coloca el ovino, hasta, la más tardía, de la catedral de León donde se repite el arquetipo iconográfico (Fig. 5) ${ }^{50}$, la nómina resulta muy rica.

-

${ }^{47}$ M. CHAMOSO LAMAS, V. GONZÁLEZ Y B. REGAL, Op. cit., pp. 80-95.

${ }^{48}$ D. OCÓN ALONSO, «El tímpano del Cordero de la basílica de Armentia», La formación de Alava. Congreso de Estudios Históricos, vol. II, Vitoria, 1982, pp. 791799 y C. B. Kendall, The Allegory of the Church: Romanesque Portals and Their Verse Inscriptions, Toronto, 1998, en particular, p. 204

${ }^{49}$ X. BARRAL I ALTET, «From late Antiquity to the Middle Ages», Sculpture. From Antiquity to the Middle Ages. From the Eighth Century $B C$ to the Fifteenth Century, Köln, 1999, pp. 249-344, especialmente, pp. 282-283; F. SALET, Cluny et Vézelay. L'oeuvre des sculpteurs, Paris, 1995 y S. BIAY, «Entre l'oeil et la main: le concept de maître sculpteur appliqué aux chapiteaux du rond-point de Cluny III et aux portails de la nef de Vézelay", À l'ombre des mots: dire et penser le Moyen Âge, Poitiers, 2007, http://janua.blog4ever. com/blog/lirarticle-68850-380168.html, consultado el 10 de agosto de 2008.

${ }^{50}$ A. FRANCO MATA, La escultura gótica en León, León, 1976, especialmente, pp. 47-70 y W. SAUERLÄNDER, «La escultura de la sede leonesa a la luz 
Teniendo en cuenta tales ejemplos parece que resulta poco viable la búsqueda de una filiación y relación formal entre ambas obras y, del mismo modo, es infructuoso hallar el origen iconográfico de esta tendencia arquetípica que marca los accesos a los edificios cristianos a través de la figura del Cordero ${ }^{51}$.

A tenor de lo expuesto, los casos más interesantes son, indudablemente, aquellos que vienen acompañados por una explicación epigráfica. En este sentido debemos mencionar el fragmento de dintel, ya comentando anteriormente, de origen francés $^{52}$. Sobre dicha estructura se esculpió la imagen del Cordero con la cruz, tal y como ya hemos señalado. Nos interesa destacar ahora la inscripción que le acompaña y que dice: ECCE DEI MISERENS AGN(US) MOEINA SISTENTES FRAT(ES) o, lo que es lo mismo: "He aquí el Cordero de Dios, lleno

de los grandes talleres europeos», La catedral de León..., pp. 177-202.

${ }^{51}$ El Éxodo XII, 7-23, relata como la sangre de los corderos pascuales inmolados sirvió para impregnar las jambas y los dinteles de las puertas de las casas de los israelitas, protegiendo así a sus primogénitos que habitaban en dichos lugares. Desde los inicios, la imagen del Cordero incide en la idea de salvación y protección, primero en las casas de los israelitas y, con el paso del tiempo y por extensión, en la casa de los cristianos -es decir, la iglesia-. Según esto, sabemos que desde la temprana Alta Edad Media la imagen del Cordero en el tondo ocupó los lugares más privilegiados del edificio, tales como el ábside o las puertas. Recuérdese, por ejemplo, el acceso a la basílica romana de Santa Prudenciana donde, a pesar de las numerosas intervenciones posteriores, parece ser, se colocó dicha imagen en torno a los siglos VIII-XI. La inscripción de la puerta deja clara la intencionalidad simbólica de dicha imagen: "Oh! tu que quieres venir al reposo de la vida eterna, aquí está abierta la entrada. Si tú vuelves aquí como exige el rito. Te llama aquél que es vía, guía, portero y que promete alegrías perdonando toda culpa". Sobre la inscripción: C. B. KENDALL, Op. cit., p. 266, quién la trancribe en los siguientes términos: $(A) D$ REQVIEm VITE CVPIS O TV QuiQUe VENIRE EN PATET INGRESSVS FVERIS SI RITE REVERSVS ADVOCAT IPSE QuiDEm VIA DVX ET IANITOR IDEm GAVDIA ProMITTENS ET CRMINA QVEQue REMIttENS.

${ }^{52}$ J-R. GABORIT, Op. cit., p. 111. de misericordia (que protege) a los hermanos que están entre estos muros" ${ }^{\prime 53}$.

Del mismo modo, la conocida clave de la bóveda del narthex de la iglesia de Saint-Pierre de Cluny, datada en el siglo XII, vuelve a mostrar al Cordero con la extremidad doblada sujetando el lábaro cristiano. Aparece de nuevo dentro de un tondo donde fue labrada la siguiente inscripción: IN CELO (sic): MAGNUS HIC PARVUS SCULPTOR UT AGNUS, es decir, "Aquí fui esculpido, cual corderito, en el cielo soy grande" ${ }^{54}$.

Tales ejemplos revelan, una vez más, la costumbre de colocar la imagen del ovino en los espacios de acceso y tránsito a los edificios, independientemente del ámbito geográfico en el que ésta se encuentre y del grado de desarrollo que alcance el contexto iconográfico en el que aparece inmersa.

\section{DEL CENTRO A LA PERIFERIA ${ }^{55}$ : EL PATROCINIO REGIO EN EL MEDIO RURAL ROMÁNICO.}

En el ámbito del norte peninsular hispano, la figura de Fernando II (11571188) aparece definida con claridad como el regnante in Legione, Gallicia et Asturiis ${ }^{56}$. Su

-

53 Realizamos la traducción a través de la tradución francesa del texto latino: "voici l'agneau de Dieu, plein de miséricorde (qui protége) les frères qui se tiennent dans ces murs", Ibidem.

54 J-R GABORIT, "Chef de voûte: l'Agenau de Dieu», France romane..., ficha catalográfica $\mathrm{n}^{\mathrm{o}}$ 161, $\mathrm{p}$. 219. El experto relaciona la pieza con los trabajos realizados en la abadía por Ponce de Melgueil y que han sido datados entre los años 1113-1118.

55 C. Ginzburg y E. CASTELnUOVo, «Centro e periferia», Storia dell'arte italiana, vol. I, Torino, 1979, pp. 283-352. En esta clásica aportación se analiza la problemática existente entre la gestación de los modelos artísticos y su difusión, desde los ámbitos de primer orden hacia los núcleos más secundarios.

56 J. M. FERNÁNDEZ CATÓN, El Reino de León y la idea imperial. Evolución Histórica, León, 2003, en especial, p. 39. Para el estudio de la figura de Fernando II, desde el punto de vista histórico y político, sigue 
importancia política se reflejó también en el importante empuje y patrocinio que prodigó a numerosas empresas artísticas ${ }^{57}$. Son bien conocidas las donaciones y favores que el monarca ofreció a las catedrales gallegas, especialmente, a la de Santiago de Compostela $^{58}$ y a la de $\operatorname{Lug}^{59}$. Sus favores también

siendo fundamental la obra de: J. GoNZÁLEZ, Regesta de Fernando II, Madrid, 1943.

${ }^{57}$ V. A. AlvÁrez PALENZUelA, «Iglesia y Monarquía en el Reinado de Fernando II», Santo Martino de León: ponencias del I Congreso internacional sobre Santo Martino en el VIII centenario de su obra literaria (11851985), León, 1987, pp. 135-151, especialmente, pp. 136141 y J. M. DE AZCÁRATE, «Fernando II de León y la iniciación del gótico», O Pórtico..., pp. 143-148.

${ }^{58}$ Véase una síntesis de dichas donaciones en: I. RUíz DE LA PEÑA GONZÁLEZ, «La reforma románica de la Cámara Santa de la Catedral de Oviedo en el contexto del patrocinio artístico de Fernando II», De Arte, 2, 2003 , pp. 29-46, pp. 32-34. No es necesario insistir en la labor del monarca como patrocinador del monumental cierre de la catedral de Santiago, el llamado Pórtico de la Gloria y en el que trabajaría el "arquitecto-gestor" Mateo. A él, el monarca concederá una pensión anual de cien maravedís sobre la participación que le correspondía en la ceca. Su interés por la sede compostelana quedó de manifiesto hasta su muerte pues, tal y como es bien sabido, acabaría por cumplir su deseo de enterrarse en ella. Cf.: I. RUIZ DE LA PEÑA, Op. cit., p. 33 y C. COSMEn Alonso y M. V. HerRÁEz ORTEGA, «Fernando II: promotor del Camino de Santiago en León», Imágenes y promotores en el arte medieval: miscelánea en homenaje a Joaquín Yarza Luaces, Barcelona, 2001, pp. 7987 , en concreto, p. 80.

Sobre las cuestiones de documentación histórica, véase: M. ReCUERO ASTRAY, P. ROMERO PORTILlA Y A. RODRÍGUEZ PRIETO, Documentos Medievales del Reino de Galicia: Fernando II (1155-1188), A Coruña, 2000, núm. 88. El documento se refiere al llamado maestro Mateo en los siguientes términos: Et ob reuerentiam sanctissimi apostoli Iacobi patroni nostri piisimi, pro munere dono et concedo tibi magistri Matheo, qui operis prefati apostoli primatum obtines et magisterium, in unoquoque anno, medietate me de moneta Sancti Iacobi (...). Véase, además: R. YZQuierdo, El Maestro Mateo, Madrid, 1991, en especial, pp. 4-5 y M. A. CASTIÑEIRAS GONZÁLEZ, El Pórtico de la Gloria, Madrid, 1999, en particular, p. 7 y pp. 16-23.

${ }^{59}$ En el caso de la sede lucense, aunque la importancia de las donaciones es menor, no dejan de ser significativas. Cf.: M. RECUERO ASTRAY, P. ROMERO PORTILLA Y A. RODRÍGUEZ PRIETO, Op. cit., núms. 7 y 61. Al igual que ocurría con el documento en el que aparece citado el "maestro" Mateo de la catedral de tuvieron como destino otras sedes del reino; en concreto, las de Ciudad Rodrigo, Salamanca, Zamora y, más claramente, las de León ${ }^{60}$ y Oviedo ${ }^{61}$.

Sin embargo, aunque siempre se ha destacado el papel jugado por el monarca en la promoción de obras proyectadas en los grandes centros del Reino, también es verdad que su labor benefició a otros núcleos de carácter más secundario. Así, encontramos bajo su protección sedes como la de Astorga, destacando también su labor constructora a lo largo de pequeños centros de carácter rural que se extendían por todo el Camino de Santiago ${ }^{62}$.

Las profesoras C. Cosmen y M. Herráez han puesto de relieve la profunda labor comitente del monarca en los núcleos de Congosto, Cacabelos, Villafranca, Foncebadón e Irago, entre otros lugares; hecho que significa una implicación promotora más allá de los grandes centros urbanos a finales del siglo XII. A ello debemos sumar el destacado papel que el monarca tuvo como consolidador de las grandes vías de comunicación que se extendían a lo largo de todo el Reino. Entre las obras más significativas destaca la redirección topográfica que ordenó llevar a cabo el rey para hacer pasar el Camino ante las puertas de la Real Colegiata de San Isidoro o la protección de nuevas zonas urbanas de la ciudad de León, tal y como ocurrió con el señorío de Renueva. También debemos a Fernando II la promoción del puente de Congosto, a partir del año 1164. A ello debemos sumar

Santiago de Compostela y en el que se le concedía una pensión vitalicia salida de la ceca, en el documento núm. 7, Fernando II aparece donando a la Catedral de Lugo y a su obispo Juan la tercia de la moneda que por entonces se acuñaba en la ciudad.

${ }^{60}$ C. COSMen Alonso y M. V. Herráez Ortega, Op. cit., p. 80 e I. RUÍZ DE LA PEÑA, Op. cit., pp. 34 y 38.

${ }^{61}$ I. RUíz DE LA PEÑA, Op. cit., p. 39.

${ }^{62}$ C. COSMEn AlONSO y M. V. Herráez Ortega, Op. cit., pp. 84-87. 
la construcción de otro viaducto, esta vez en Coyanza, en torno al año $1168^{63}$.

Pero volvamos finalmente a los dos tímpanos románicos y cuestionemos las posibles conexiones que se pueden establecer entre estas dos piezas románicas del entorno rural y las obras existentes en la capital durante estos años finales del siglo XII. La primera de ellas, de mayor calidad $\mathrm{y}$, por lo tanto, obviamente de la que derivaría el modelo más tosco, es la esculpida para la portada de la iglesia de los santos Julián y Basilisa de Ruiforco. Ya hemos señalado que la mayoría de los especialistas vienen datándola en torno a la segunda mitad del siglo XII, y que suele vincularse estilística e iconográficamente con la Real Colegiata de San Isidoro de León.

Desde el año 931, tenemos constancia de la existencia del monasterio de Ruifor$\mathrm{Co}^{64} \mathrm{y}$ parece ser que las relaciones con el de

63 J. M. FERNÁNDEZ CATÓN, Colección documental del archivo de la Catedral de León, 1109-1187, vol. V, León, 1990, núm. 1546. En él aparece el monarca como donante de su realengo de Aulacas y Pobladura, con las iglesias de San Cosme y San Damián, junto con tres solares en Secos "a fin de que construyan y concluyan el puente de Coyanza".

${ }^{64}$ J. M. FERNÁNDEZ CATÓN, Colección documental..., núm. 89: donde aparece mencionado Alfonso IV en un pleito existente entre los monjes del monasterio de Ruiforco contra los habitantes de Manzaneda y Garrafe. En el citado documento se habla del monasterio en los siguientes términos: In era DCCCCLXVIIII orta fuit contemtio inter parte de frates de monasterio Sancti Iuliani, qui est fundatum super ripa de ribulo Torio, in suburbio ciuitatis Legionense (...).

Por su parte, el padre Flórez también recoge algunos datos al respecto: "En la era 969 se movió cierto pleyto entre los vecinos de Manzaneda y los monjes del Monasterio de San Julián y Basilisa de Ruiforco, que estaba fundado à la ribera del Torio. La causa fue que los habitantes de dicha villa se introdugeron à egercer actos de jurisdicción y dominio dentro de los terminos de la misma villa, siendo que ésta habia sido propria de Rumforco fundador del expreso monasterio, y los monges la poseian por concesion y confirmacion de los Reyes Don Alfonso y Doña Ximena, y Don Ordoño II y Doña Elvira: los Monges y Garsea yerno del fundador de Rumforco, y los vecinos de Manzaneda se presentaron juntos al Rey Don Alfonso IV y propusieron
San Isidoro de León pueden remontarse, sin problemas, al reinado de Alfonso V (9991027). Este monarca había trasladado los restos del rey Alfonso IV (928-933) desde dicho monasterio donde se encontraba enterrado junto a Alfonso Froilaz, hasta el Panteón de la iglesia de San Juan Bautista, posteriormente, puesta bajo la advocación del santo visigodo y que el mismo monarca Alfonso V había mandado construir ${ }^{65}$.

Ya desde el año 1063, con Fernando I y doña Sancha, el monasterio de Ruiforco pasó a formar parte del Infantado, hecho que corrobora la temprana dependencia del monasterio de Ruiforco con respecto a San Isidoro $^{66}$. Sin embargo, las relaciones entre el cenobio del Torío y la Real Colegiata se amplían en el tiempo hasta el reinado de Fernando II (1157-1188), periodo que, cronológicamente, coincide con la datación que tradicionalmente se ha venido otorgando al tímpano. Fue en 1159, tal y como apunta J. M. Rodríguez Montañés, cuando el monarca "ordenó la restitución a San Isidoro de León del monasterio de San Julián y Santa Basilisa de Ruiforco (...) apareciendo ya en el

sus quejas y alegaron las razones que favorecian à cada una de las partes. El rey tomó la determinación de reconocer personalmente los terminos, y habiendo ido à la referida villa acompañado de muchos Grandes se registraron los documentos, y se examinó lo que sabían los ancianos, y conforme à esto fueron señalando los límites imponiendo graves penas à los contraventores. Hizose escritura de este acto tan solemne y autorizado à 9 de Enero y la firmaron el Rey y los dos Obispos de León, Cixila el retirado, y Oveco que actualmente presidía": E. FLÓREZ, España sagrada, Iglesia antigua de León (ed. Facsímil), vol. XXXIV León, 1980, p. 240 .

${ }^{65}$ J. M. FERnÁNDEZ CATÓN, El Reino de León..., p. 27. Sobre el cementerio regio existente en San Juan Bautista de León, véase: J. A. MORÁIS MORÁN, La recuperación de la Ecclesiae Primitivae Forma en la escultura del Panteón Real de San Isidoro de León, León, 2008. Sobre el el papel problemático jugado por Alfonso V en la construcción de la iglesia de San Juan Bautista de León, consúltese: M. VALDÉS FERNÁNDEZ, «El Panteón Real de la Colegiata de San Isidoro de León», Maravillas..., pp. 73- 84, en particular, pp. 74-75.

${ }^{66}$ J. M. RODRÍGUEZ MONTAÑ́́S, Op. cit., p. 205. 
privilegio de Alejando III de 1163 y en su confirmación de 1176 entre las posesiones isidorianas $^{\prime 67}$

Ello indica, claramente, la vinculación del pequeño monasterio al gran centro artístico de la capital leonesa. Un templo que, a pesar de que había alcanzado ya su máximo esplendor creativo dentro de las artes románicas y de que su iglesia había sido consagrada en el 1149, no cayó en la inactividad. En este sentido, aún en el año 1167 encontramos citados en algunos documentos del Archivo de la Real Colegiata de San Isidoro de León a pedreros y carpinteros que nos indican la continuación de los trabajos en la fábrica ${ }^{68}$. Incluso, tal y como recogen las profesoras C. Cosmen y $\mathrm{M}$. V. Herráez, cuatro años después de este hecho, aparece entre la documentación un operario llamado Cipriano, de Fenar, que es donado por el rey Fernando II, con el fin de trabajar en las obras de la basílica legionen$\mathrm{se}^{69}$.

Según estos datos, queda claro entonces que las obras de la Real Colegiata se encontraban activas aún en la segunda mitad del siglo XII, aunque fuese ya de manera inercial y alejadas de las creaciones excepcionales del inicio de siglo. San Isidoro, después de las obras tardorrománicas en la catedral de León, continuaba en este periodo siendo un centro de referencia para el trabajo de artistas y maestros.

Tanto el tímpano de Ruiforco como el de Matueca se hallan, desde un punto de vista geográfico, vinculados a la ribera del Torío, territorio muy cercano a la localidad de Fenar. Este dato es fundamental para localizar el lugar del que debió salir la piedra que sirvió para esculpir ambos tímpa-

${ }^{67}$ Ibidem.

${ }^{68}$ C. Cosmen Alonso y M. V. Herráez OrtegA, Op. cit., en especial, p. 82.

${ }^{69}$ Ibidem. nos, pues las canteras de Fenar, sin duda, las más ricas de toda la región, junto con las de Boñar, abastecerían desde bien temprano las fábricas de San Isidoro de León y las de la catedral tardorrománica de la misma ciudad. Ésta última fábrica se encontraría a finales del siglo XII en plena activi$\operatorname{dad}^{70}$.

A este edificio dedicado a Santa María, aparecen ligados nombres como los de Pedro Cibriánez, maestro activo en la obra catedralicia en el año $1175^{71}$. A él debemos sumar el trabajo de otro operario llamado Pedro Esteban, que en 1177 fue donado a la obra catedralicia por el monarca. Tal y como indica el documento en el que aparece citado, trabajaba en una cantera a la que ya hemos aludido: la de Robledo de Fenar ${ }^{72}$. Pues bien, llegados a este punto debemos señalar que, tanto el operario donado por Fernando II a las obras de San Isidoro, co-

${ }^{70}$ C. Cosmen Alonso, M. V. Herráez ORTEGa y M. VALDÉS FERNÁNDEZ, «La Edad Media...», pp. 33-37. Según los autores, dicha catedral pudo iniciarse bajo el patrocinio de Juan Albertino (1139-1181) y continuarse durante el episcopado de don Manrique de Lara (11811205). Las noticias que recogen hablan de un claustro finalizado en torno al año 1200 y la posibilidad de que, durante su mandato, se hubiera eregido una "iglesia mayor tardorrománica, construída entre la de Pelayo y la gótica, resuelta en su mayor parte durante el episcopado de Manrique de Lara". Sobre la desvinculación de la figura de Manrique de Lara con respecto al proyecto gótico de la catedral y el patrocinio de un edificio tardorrománico, véase: M. V. HERRÁEZ ORTEGA, Op. cit., particularmente, p. 147.

${ }^{71}$ C. COSMEN AlONSO, M. V. Herráez ORTEga y M. VALDÉS FERNÁNDEZ, «La Edad Media...», pp. 33-34 y C. Cosmen Alonso y M. V. Herráez Ortega, Op. cit., p. 81.

${ }^{72}$ C. COSMEn Alonso y M. V. Herráez Ortega, Op. cit., p. 81. Las autoras hacen alusión al documento publicado en: J. M. FERNÁNDEZ CATÓN, Colección documental..., núm. 1603. En él Fernando II dona a las obras de la iglesia de Santa María de León un molino que posee en la presa del Torío. Igualmente otorga al hominem illum Petrum Stephani, que vivía en Robledo de Fenar, iuxta illam petrariam. Junto con él también cede el realengo de Rabanal de Fenar, con la iglesia de Santa Justa y con la de San Jorge en Brugos de Fenar. 
mo éste, llegado a las obras de la catedral tardorrománica por el mismo sistema; parecen desarrollar parte de sus trabajos como canteros en la zona de Fenar, de donde se tomaría parte de la piedra para ambas fábricas.

La localidad de Ruiforco, de donde procede el tímpano de la iglesia de San Julián, se encuentra situada, aproximadamente, a $10 \mathrm{~km}$ de dicha cantera de Robledo de Fenar. La profunda actividad de las explotaciones lapídeas quedaría demostrada por las continuas ventas de tirras vinculadas siempre con este territorio, con el objetivo de beneficiar al avance constructivo de la catedral leonesa ${ }^{73}$. Debiéramos preguntarnos a tenor de lo expuesto, si las continuas ventas de tierras relacionadas con las canteras de Fenar (Rabanal, Candanedo, Robledo, Brugos, etcétera...) reflejan de manera indirecta una continua explotación de la piedra que luego sería aprovechada en los trabajos arquitectónicos y escultóricos de las grandes fábricas de la ciudad de León. Por otra parte, esta serie de datos parecen señalar la vía rural que unía estos núcleos rústicos con la capital como uno de los canales más ricos e interesantes en los que situar algunos de estos intercambios

${ }^{73} \mathrm{Al}$ respecto véanse los siguientes documentos: J. M. FERNÁNDEZ CATÓN, Colección documental..., núm 430/1927, del año 1225, en el que se vende al canónigo de la catedral de León una tierra en Rabanal de Fenar; núm. 468/1954, del año 1228 y en el que se vende a don Gutierre, canónigo de la iglesia de León y con destino a la obra de la iglesia de Santa María, una tierra en Rabanal de Fenar; núm. 1971. Del año 1230, data el documento mediante el cual se vende a Gutierre Didaci, canónigo de León, dos tierras situadas en Rabanal de Fenar destinadas a las obras de Santa María. Una de las menciones más importantes aparece en el documento núm. 1916 del año 1223, en el que Abril Roderici otorga a favor de la obra de la iglesia de Santa María la tierra llamada "de la Uxola", situada entre Brugos de Fenar y Rabanal de Fenar, así como todo lo que había sido vendido y donado a la obra de dicho edificio, en todo el valle de Fenar. artísticos; en definitiva, un "viaje" de ida y vuelta, tanto de artífices como de ideas.

Parece evidente que los escultores de Ruiforco y Matueca debieron salir de dichas canteras y al igual que la piedra empleada para su labra. La actividad en la cantera próxima al lugar en el que fueron esculpidos los tímpanos, la actividad artística en la basílica de San Isidoro durante el último cuarto del siglo XII, y la donación de Fernando II en 1168 a la Real Colegiata del operario Cipriano de Fenar, hacen posible intentar justificar la dependencia de modelos entre la basílica de San Isidoro y la obra rural de Ruiforco e inscribir ambos tímpanos dentro del empuje que este monarca proporcionó a las artes del periodo.

La hipotética cronología que defendemos desde el punto de vista documental para estos tímpanos, viene confirmada por algunos elementos estilísticos que muestran las esculturas. En esta línea, los elementos vegetales que flanquean las escenas de ambos tímpanos, deben ser, a nuestro juicio, emparentados con el arte llevado a cabo en Hispania alrededor del año 1200, aunque si bien se pudiera barajar perfectamente un arco temporal que abarcase los años iniciales del XIII (Fig. 6). Simplemente debemos realizar un breve repaso por las principales fábricas a finales de siglo para poder adscribir dichas representaciones vegetales a los talleres activos en torno a esta fecha ${ }^{74}$.

\footnotetext{
${ }^{74}$ Observamos similitudes, más o menos formales, entre la representación derecha del tímpano de Ruiforco con la larga serie de motivos vegetales del Pórtico de la Gloria, a pesar de que, como es normal, la calidad del tímpano sea muy inferior. Por ejemplo, advertimos semejanzas con los capiteles de la cripta baja del Pórtico de la sede compostelana -allí mucho más delicados y jugosos-. Se puede rastrear idéntico motivo en algunos de los lugares donde se ha detectado la tan manida "influencia mateana": desde los elementos vegetales de algunos capiteles de la portada sur de la iglesia de San Juan de Portomarín, a los de la portada
} 
En este sentido, podemos apoyarnos en el análisis llevado a cabo por la profesora Etelvina Fernández González, a propósito de las formas vegetales presentes en algunos manuscritos iluminados salidos del scriptorium de la Real Colegiata de San Isidoro y atribuidos a Santo Martino. La autora diferencia dos tipos de vegetales: el acanto inglés y las hojas cuenco, tipología ésta última que deriva del acanto inglés ${ }^{75}$. Según la distinición que establece la citada investigadora, el vegetal de Ruiforco se podría emparentar con una especie de hoja-cuenco invertida que "se caracterizan por que toman las formas de recipientes al volverse los extremos hacia la zona inferior de la hoja $(. . .)^{76}$.

Idénticos resultados obtenemos al comparar estas formas, con otras produc-

occidental de San Esteban de Ribas de Miño, también con reminiscencias "mateanas".

Sobre los talleres derivados del Pórtico de la Gloria en Galicia, en una cronología posterior al año 1200, véase: S. M. FERNÁNDEZ PÉREZ, San Esteban de Ribas de Miño. Los talleres de filiación mateana, Lugo, 2004, en particular pp. 90-99.

En el resto del reino catellano-leonés, fórmulas parecidas aparecen en la iglesia de la Magdalena de Zamora o en la Puerta del Obispo de la misma ciudad, donde localizamos motivos que se podrían encuadrar en la misma línea estilística. Cf.: E. FERNÁNDEZ GONZÁLEZ, «Presencia de Oriente y Occidente...», pp. 225274.

${ }^{75}$ E. FERNÁNDEZ GONZÁLEZ, «Abecedario bestiario de los códices de Santo Martino», en A. VIÑAYO GONZÁLEZ Y E. FERNÁNDEZ GONZÁLEZ, Abecedario-bestiario de los códices de Santo Martino, León, 1985, pp. 41-96, en especial, pp. 52-53.

${ }^{76}$ Ibidem y F. GALVÁN FREILE, Fragmentos de manuscritos iluminados en el Archivo Histórico Provincial de León (ca. 1200), León, 2000, pp. 34-35 y pp. 80-82. El profesor Galván considera este motivo como carácterístico de la miniatura próxima al año 1200 . Véase la similitud entre el elemento vegetal esculpido en el tímpano y la miniatura del fragmento 19, carpeta Ponferrada I, f. 1r?. C?.

Se trata de una inicial decorada con elementos fitomórficos de los que "surge una gran hoja que vuelve sus extremos sobre sí misma o sobre el tallo del que surge". El estudioso data la miniatura alrededor del 1200, aunque permite, igualmente, adelantarla hasta 1180, en comparación con modelos portugueses. ciones escultóricas contemporáneas. En lo referente a la gran obra arquitectónica de la ciudad, la catedral tardorrománica, una de las enjuntas que posiblemente pertenecieron a dicho conjunto, presenta una genealogía de vegetal carnoso que está en la misma línea estilística y cronológica que el representado en el tímpano de Ruiforco ${ }^{77}$. Un fenómeno similar constatamos al comparar dichos motivos con la escultura de otro de los grandes monasterios del reino: el de San Benito de Sahagún. Algunos de los capiteles vegetales del transepto, datandos a fines del siglo XII, presentan hojas jugosas muy análogas ${ }^{78}$.

Por último y aunque menos decisivo, también encontramos indicios para datar los dos tímpanos que estudiamos a través del método iconográfico, pues el simbolismo del Cordero Pascual con lábaro se encontraba perfectamente difundido durante los últimos años del siglo XII. Así fue representado en la clave de la bóveda cuatripartita de la tribuna que remata la magna obra del Pórtico de la Gloria, también ligada,

${ }^{77}$ La enjunta se conserva actualmente en León, Museo Diocesáno. Sobre las obras escultóricas del periodo, véase; M. VALDÉS FERNÁNDEZ, C. COSMEN Alonso y M. V. Herráez OrtegA, «La Edad Media...», en particular, p. 46. Estos autores hablan de una filiación 1200 para esta pieza. También consúltese: G. ВотO VARELA, «Catedral de Santa María de Regla», Enciclopedia del románico..., pp. 589-602, en particular, p. 592.

${ }^{78}$ M. V. Herráez Ortega, C. CoSmen ALONSO, E. FERNÁNDEZ GONZÁLEZ Y M. VALDÉS FERNÁNDEZ, «La renovación del monasterio en el reinado de Alfonso VI», Esplendor y decadencia de un monasterio medieval. El Patrimonio artístico de San Benito de Sahagún (M. Victoria Herráez Ortega coord.), León, 2002, pp. 51-77, en especial, p. 99. Véanse los capiteles representados en las figuras 34, 35 y 42 . A ellos debemos sumar los capiteles, todos ellos datados en los años finales del siglo XII, de la portada sur de la iglesia de San Pedro de Montes o de la portada de San Julián de Astorga, donde el concepto morfológico del vegetal siempre se mantiene. Cf.: J. M. RODRÍGUEZ MONTAÑÉS, «Iglesia de San Julián (hoy Nuestra Señora de Fátima)», Enciclopedia del románico..., pp. 446-449, en particular, p. 449. 
como hemos señalado, a la figura de Fernando $\mathrm{II}^{79}$. Sus repercusiones en todo el arte románico gallego y leonés, desde finales del siglo XII y principios del XIII, han sido puestas de relieve en numerosas ocasiones, no faltando tampoco los ejemplos en los que el Cordero aparece acompañado de algunos elementos vegetales, tal y como se puede ver en el tímpano de San Pedro de Fora $^{80}$.

Muy cerca de León, y en una cronología, similar, se volvió a utilizar el tema en la iglesia de Santa María de Azogue, auspiciada de nuevo por Fernando II, y que guarda puntos en común, tanto con el tímpano del Cordero de la basílica isidoriana

${ }^{79}$ El profesor Serafín Moralejo dio una lectura, aún hoy en plena vigencia, para dicho conjunto. El Agnus Dei aparece aquí según la visión apocalíptica de San Juan. Cf.: S. MORAlEjO ÁlvAREZ, «La imagen arquitectónica de la catedral de Santiago de Compostela», Atti del Convengo Internazionale di Studi: Il pellegrinatio a Santiago de Compostela e la letteratura jacopea, Perugia, 1985, pp. 37-61, en reedición Patrimonio artístico de Galicia y otros estudios. Homenaje al Profesor Serafín Moralejo, vol. I, Santiago de Compostela, 2004, pp. 237263, especialmente, pp. 242-244; R. YZQUIERDO, Op. cit., p. 17 y M. A. CASTIÑEIRAS, Op. cit., p. 53.

Resulta interesante comparar la colocación de la imagen del Cordero en la catedral de Santiago con la clave colocada en el narthex de la abadía francesa de Cluny. No en vano, se ha vinculado la utilización de dicha imagen al fenómeno de la Reforma Gregoriana y su interés por exaltar estos símbolos del primer arte cristiano. Siguiendo las ideas de Weisbach, el Pórtico de la Gloria de Santiago supo asumir perfectamente esta tendencia ideológica en auge aún a finales del siglo XII. Cf.: W. WEISBACH, Reforma religiosa y arte medieval. La influencia de Cluny en el románico occidental, Madrid, 1949, en especial, p. 118.

${ }^{80}$ Ya hemos aludido a los existentes en las iglesias de Moraime y Santa María de Cambre, en A Coruña. A ellos debemos sumar otros, como los de Camanzo, el de la puerta norte de la iglesia de Santiago, en la misma región gallega o este que citamos de San Pedro de Fora -hoy en una colección particular en Barcelona-. Cf.: R. YZQUIERDO, Op. cit., ficha catalográfica núm. 13. como con los tímpanos de Ruiforco y Matueca de Torío ${ }^{81}$.

Según lo argumentado hasta el momento, las relaciones existentes entre los principales centros de la producción artística románica hispana, en particular, la del reino de León y aquellos pertenecientes a una órbita más rural, fueron enormemente complejas. Las canteras abiertas en las fábricas más importantes acabaron influenciando, ocasionalmente, los trabajos llevados a cabo en lugares más secundarios. Así, los artífices escultores activos en la iglesia de San Isidoro durante la primera mitad del siglo XII, dejaron una fuerte impronta en aquellos que trabajaron en las obras hoy conservadas en Ruiforco y Matueca de Torío. A pesar de que sus labores puedan ser inscritas en los años finales de ese siglo y los primeros deceniso del siguiente, el uso de fórmulas estilísticas gestadas cincuenta años antes evidencia notoriamente los sistemas de creación utilizados por los artistas románicos, así como las relaciones entre los medios más selectos y elitistas con respecto a las áreas más ruralizadas.

Igualmente significativa resulta la comitencia regia pues, según parece, debe-

${ }^{81}$ J. M. Rodríguez MONTAÑÉS, «Iglesia de Santa María de Azogue», Enciclopedia del románico en Castilla y León. Zamora, Aguilar de Campoo, 2002, pp. 188-202, en particular, p. 188 y p. 194. La portada de esta iglesia de la localidad de Benavente, presenta dentro de su iconografía una síntesis de elementos esculpidos en las dos portadas historiadas existentes en la Real Colegiata de San Isidoro de León. Así, mientras que el motivo central de la fachada presenta la imagen del Cordero Apocalíptico enmarcado en un clípeo -motivo tomado literalmente de la Puerta del Cordero-, en los laterales y en la parte alta fueron colocados cuatro ángeles turiferarios que recuerdan a los existentes en la otra portada del edificio, la del Perdón.

Véase también: J. A. MORÁIS MORÁN, “La efigie del rey David...", (en prensa) e ID., "Nuevas reflexiones para la lectura iconográfica de la Portada del Perdón de San Isidoro de León: el impacto de la Reforma Gregoriana y el arte de la tardoantigüedad», De Arte, 5, 2006, pp. 63-86. 
mos atribuir a Fernando II un papel decisivo en el patrocinio edilicio y artístico llevado a cabo en el norte de la Península Ibérica durante los últimos decenios del siglo XII. Una labor de mecenazgo no sólo vinculada a la capital del reino, sino también a otros centros eminentemente periféricos y de menor envergadura, representados, en este caso particular del arte románico español, a través de los dos tímpanos analizados en este trabajo.

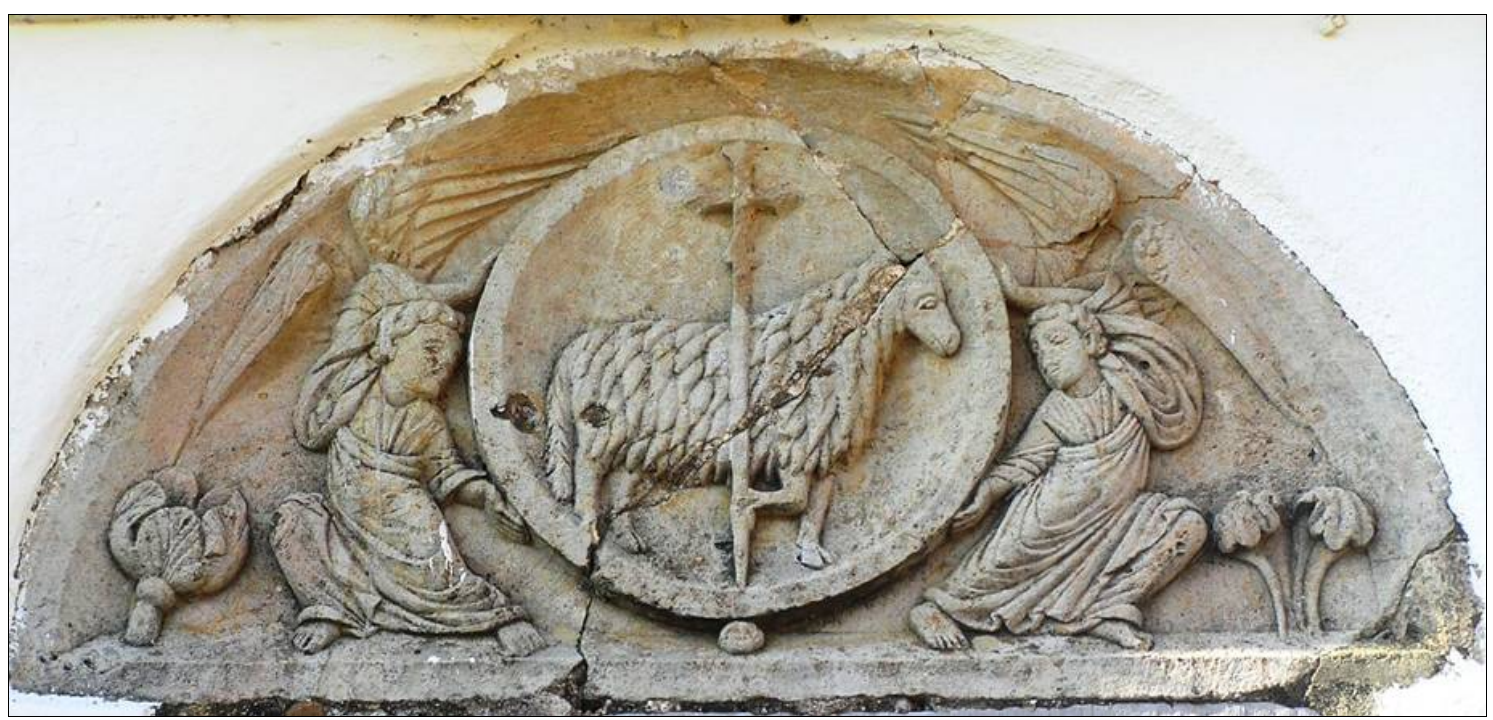

- Fig. 1. Tímpano. León, Ruiforco de Torío, iglesia de San Julián. 


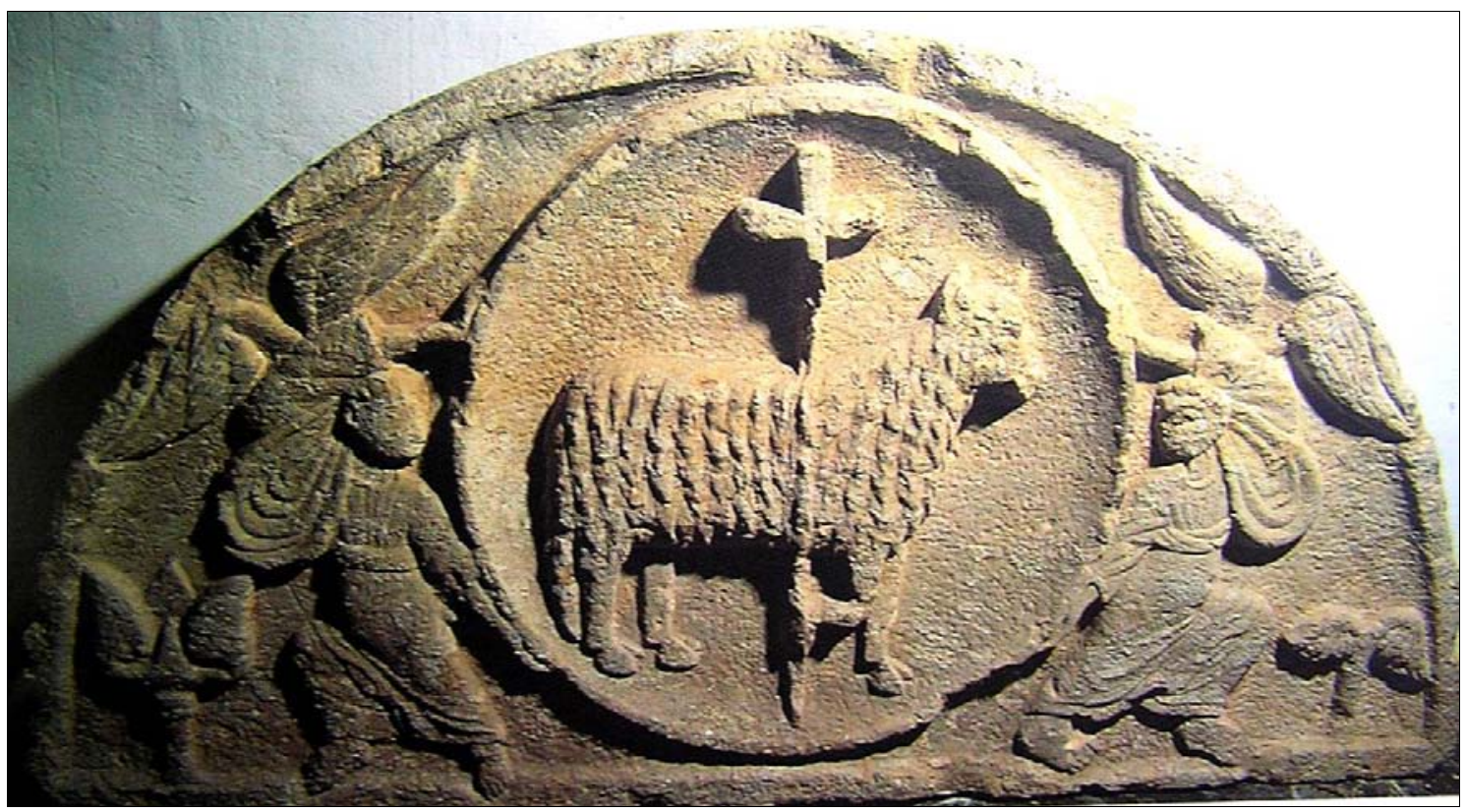

- Fig. 2. Tímpano. León, Matueca de Torío, iglesia de San Tirso.

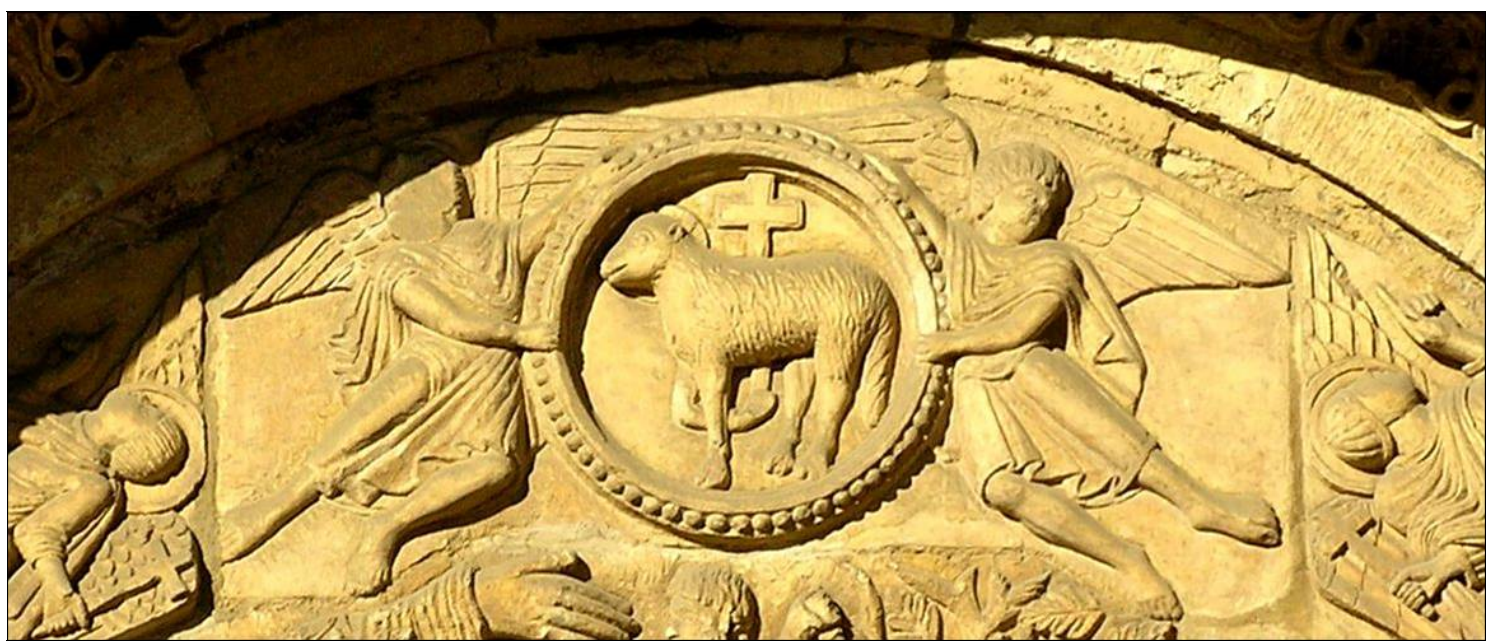

- Fig. 3. Tímpano. León, iglesia de San Isidoro, puerta del Cordero. 


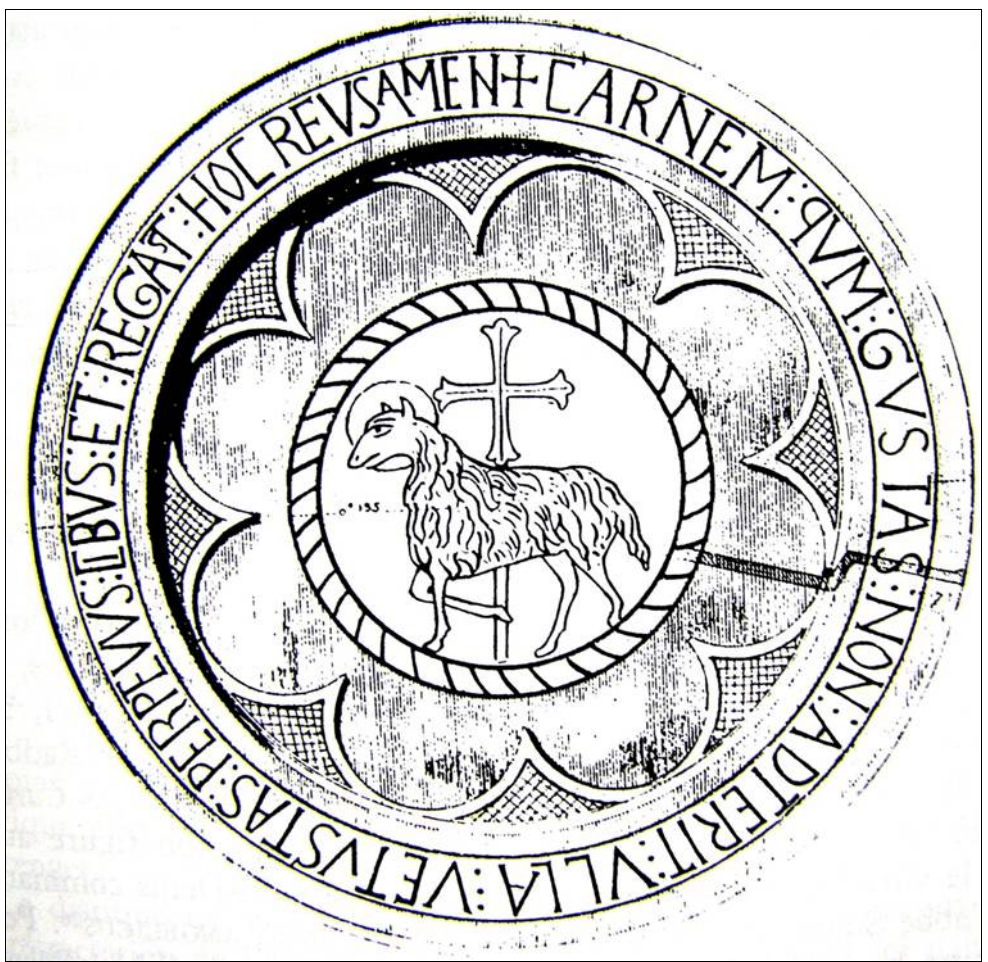

- Fig. 4. Patena del abad Pelayo. París, Museo del Louvre. Procede de Santiago de Peñalba (León). (Según R. Favreau).

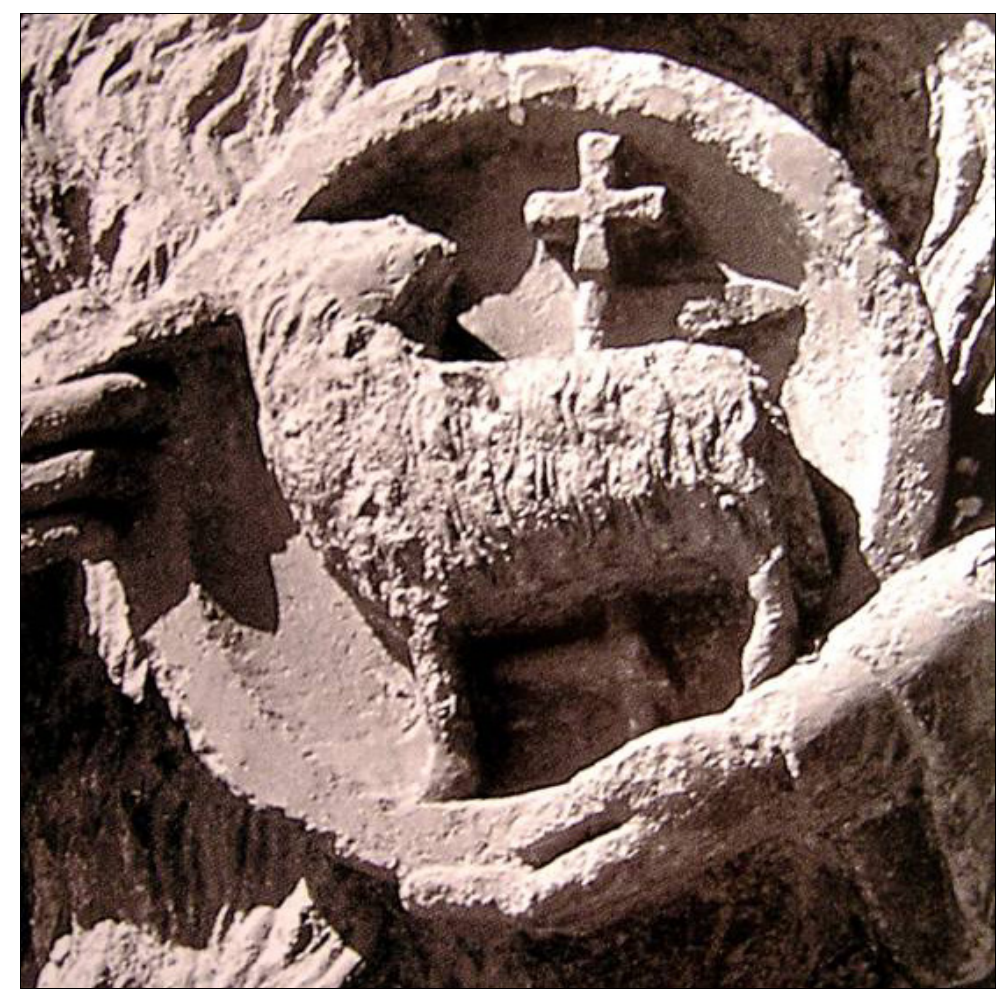

- Fig. 6. Patena con el Agnus Dei. León, catedral, San Juan Bautista. 


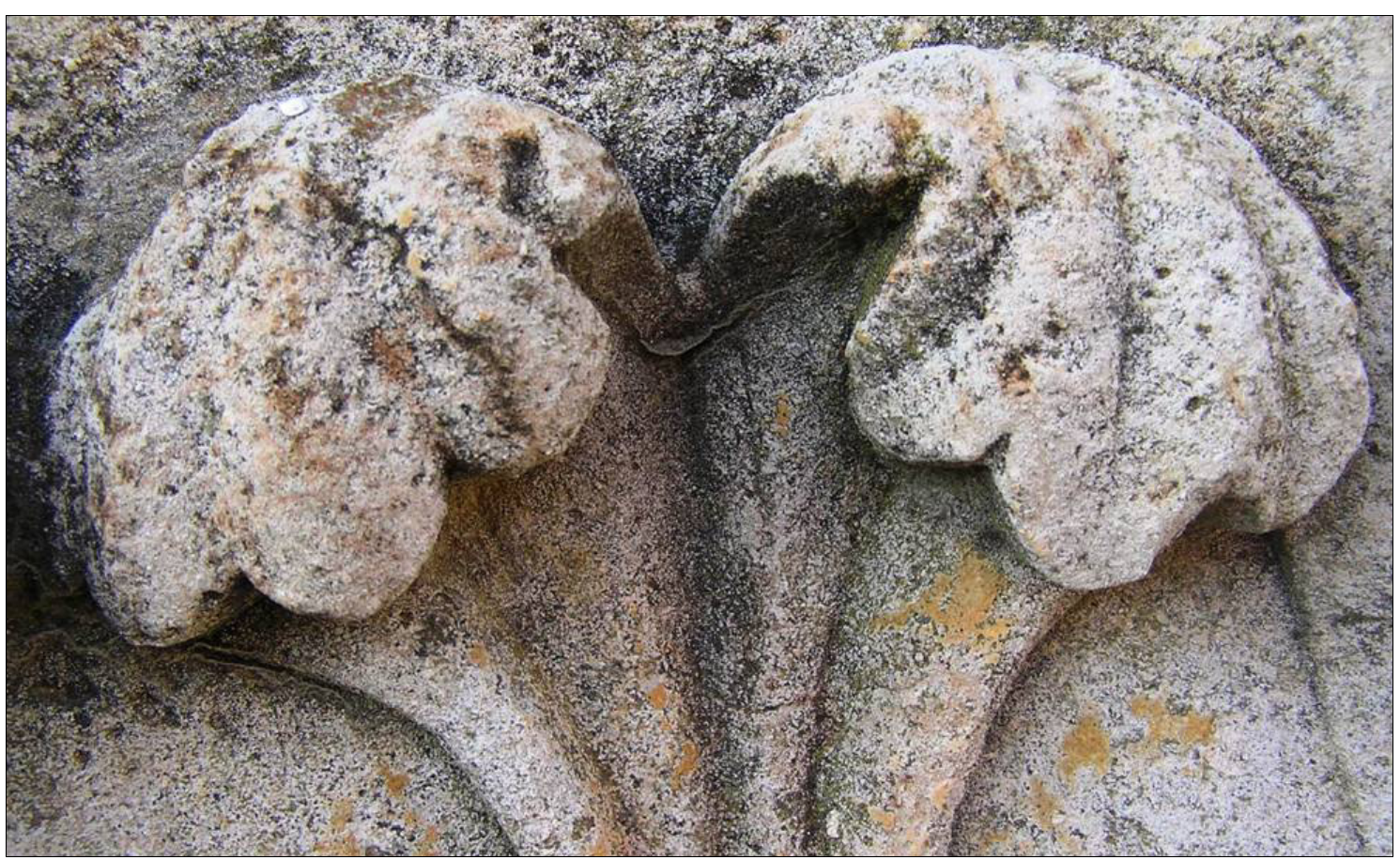

- Fig. 5. Patena con el Agnus Dei. León, catedral, San Juan Bautista. 